\title{
The shallow and deep hypothesis: vertical chemical contrasts shape nitrate export patterns from different land uses
}

\author{
Wei Zhi ${ }^{1}$ and $\mathrm{Li} \mathrm{Li}^{1}$ \\ ${ }^{1}$ Pennsylvania State University
}

May 5, 2020

\begin{abstract}
Excessive nutrients have penetrated water bodies worldwide yet our forecasting capabilities remain elusive. This work tests the shallow and deep hypothesis: chemical contrasts in the subsurface shape nitrate export patterns. We use data synthesis for 228 U.S. watersheds and reactive transport modeling (500 simulations) spanning broad climate, geology, and land conditions. Data synthesis showed that human perturbation has amplified chemical contrasts in shallow versus deep waters, inducing primarily flushing patterns (concentration increase with streamflow) in agriculture lands and dilution (concentration decrease with streamflow) patterns in urban watersheds. Data and model reveal a general relationship between export patterns and shallow versus deep nitrate contrasts. This underscores the often-overlooked role of $\mathrm{N}$ distribution over depth. The results challenge commonly-held perception that legacy stores in agricultural lands induce chemostasis with negligible concentration variations with discharge. They suggest nutrient export will exacerbate as extreme events such as flooding intensify in the future climate.
\end{abstract}

\section{INTRODUCTION}

Eutrophication in rivers, lakes, and coastal areas worldwide has persisted for decades due to intensive agriculture and urbanization (Diaz \& Rosenberg, 2008; Galloway et al., 2004; Le Moal et al., 2019; Royer et al., 2006; Van Cappellen \& Maavara, 2016; Van Meter et al., 2017). In the U.S. alone, over 60\% of U.S. estuaries and coastal water bodies have been degraded by excessive nutrient inputs (Howarth et al., 2002). The concentration levels and export patterns of nitrate, a major dissolved nitrogen $(\mathrm{N})$ species, are essential to understand and quantify $\mathrm{N}$ export from terrestrial to aquatic ecosystems. Export patterns are often quantified using concentration - discharge (C-Q) relationships with a power law of $\mathrm{C}=a \mathrm{Q}^{b}$. The C-Q relationships determine loads of solute export (load $=\mathrm{C} \times \mathrm{Q})$ and reflect the response of earth systems to hydrological changes. The value of $b$ indicates different export patterns: a positive, high value means a flushing pattern where concentrations increase with streamflow, whereas a negative $b$ indicates decreasing concentrations with streamflow (Godsey et al., 2009; Moatar et al., 2017; Musolff et al., 2015). Chemostatic patterns (with absolute b values close to zero) occur when concentrations vary little compared to hydrological variations. These export patterns have important implications on how and how much nitrate exports across different hydrological regimes. High bvalues with pronounced flushing patterns indicate highly sensitive, escalated export during extreme hydrological events such as flooding.

Agriculture and urbanization have significantly modified subsurface physical and chemical structures, including the spatial distribution of N (Figure 1). Agricultural lands are often characterized by shallow flow via tile drainage and heavy fertilization that enriches $\mathrm{N}$ in shallow soils (Van Meter et al., 2016; Woo \& Kumar, 2019). Urban watersheds represent a different type of human perturbation, often characterized by impervious surfaces that facilitate surface runoff during storms and sewer pipes that enhance rapid shallow subsurface flow (Grimm et al., 2008). Nitrogen in urban watersheds can come from a variety of surface and underground sources including atmospheric deposition, lawn fertilizers, and domestic and industrial 
wastewater (Baker et al., 2001; Divers et al., 2014). Buried leaky sewer systems often elevate the N input to urban groundwater (Groffman et al., 2003; Pickett et al., 2011). These manipulations do not occur in undeveloped, pristine watersheds, where $\mathrm{N}$ content is often low and tightly cycled (Weitzman \& Kaye, 2018). These differences, in particular their vertical distribution of $\mathrm{N}$ content, can lead to distinct $\mathrm{C}-\mathrm{Q}$ patterns across different land use conditions.

Given the tremendous human influence, an open question that is key to understand nutrient export is: How do subsurface physical and chemical structures from different land uses in governing nitrate export patterns? Contrasting observations in literature do not converge to a unifying framework that answers these questions. In agricultural lands, both dilution and flushing have been observed (Jiang et al., 2010; Miller et al., 2017). The common perception is that chemostasis or biogeochemical stationarity prevails in agriculture lands, primarily due to the large legacy store of nitrogen $(\mathrm{N})$ that induces transport limitation and buffers concentration variability (Basu et al., 2010; Basu et al., 2011; Thompson et al., 2011). In undeveloped, forest watersheds, nitrate concentrations have been shown to often peak during spring floods (Creed \& Band, 1998; Creed et al., 1996; Pellerin et al., 2012; Sickman et al., 2003), whereas chemostasis has not been as commonly observed (Huang et al., 2012; Jacobs et al., 2018). Although much less examined, existing urban studies have observed both dilution (Duncan et al., 2017) and flushing patterns (Poor \& McDonnell, 2007; Wollheim et al., 2005).

Growing literature has recognized the importance of subsurface structure, particularly the hydrological and biogeochemical contrasts in shallow and deeper zones in governing nitrate levels, denitrification potentials (Bishop et al., 2004; Creed et al., 1996; Kolbe et al., 2019), and solute export in general (Musolff et al., 2017; Zhi et al., 2019). Seibert et al. (2009) developed a flow-concentration integration model that quantitatively links variations of stream chemistry to flow rates and vertical profile of shallow soil water chemistry. Zhi et al. (2019) showed that vertical chemical contrasts between shallow soil water and deeper groundwater can explain diverse export patterns in multiple watersheds under a gradient of climate, geology, and land cover conditions. Here we propose the shallow versus deep hypothesis: the $N$ concentration contrasts in shallow and deep zones determine nitrate export patterns under different land use conditions . In particular, we hypothesize that nitrate concentration contrasts in shallow water $\left(\mathrm{C}_{\mathrm{sw}}\right)$ and deep water $\left(\mathrm{C}_{\mathrm{dw}}\right)$ differ in different land uses, and that the magnitude of concentration contrasts governs export patterns. Here "shallow water" and "deep water" are broadly defined as waters from different depths contributing to streams (Figure 1). The shallow water can come from the shallow surface / subsurface zone that dominates streamflow at high flow; the deep water may derive from deeper subsurface zones and predominate at low flow. These shallow and deep waters are loosely defined. In pristine sites, the shallow water may be the shallow soil water; in agriculture sites, it can be the combination of surface runoff, tile drainage, and soil water; in urban lands, it may be the runoff from impervious surfaces and shallow subsurface pipes. The deep water is the groundwater that interacts with streams and carries chemical signatures that are distinctive from shallow water.

If this hypothesis is true, we expect higher concentrations in shallow water in agricultural lands, leaning more toward a flushing pattern. In contrast, in urban watersheds, concentrated nutrients accumulated in leaky pipes in deeper subsurface are often higher than shallow, rapid runoff on impervious surfaces, leading more toward a dilution pattern (Duncan et al., 2017). Nitrogen in forests and pristine sites can come from decomposition from organic matter in shallow soils and leaching from N-containing rocks (Mayer et al., 2002; Montross et al., 2013). In addition, they are often tightly cycled. These characteristics can lead to varied patterns. We test this hypothesis combining a national-scale synthesis for 228 sites in the United States data synthesis and mechanism-based reactive transport modeling. Our goal is to propose a general, simple conceptual model that can explain and quantify export patterns under diverse conditions.

\section{APPROACHES AND METHODS}

Water data source. Nitrate data from 228 sites across the contiguous United States were analyzed. This includes 147 sites from the National Water-Quality Assessment (NAWQA) project, a network established to monitor stream water quality since 1991 (Spahr et al., 2010). The NAWQA has daily discharge records and 
monthly water quality data across four land use categories: Agriculture, Mixed, Undeveloped, and Urban. The NAWQA sites have median and mean drainage areas of 150 and $294 \mathrm{~km}^{2}$, respectively. The USGS Water Quality Watch (WQW) database (https://waterwatch.usgs.gov/wqwatch/) includes 71 sites and continuous water quality data (5 minutes to hourly) since 2014 . The WQW sites are primarily located in the Midwestern "Corn Belt" (e.g., Iowa, Illinois, Indiana) with sizes ranging from 1 to $>29,000 \mathrm{~km}^{2}$. The USGS discharge and nitrate data were retrieved from the National Water Information System (https://waterdata.usgs.gov/nwis).

We also examined intensively-measured data in 6 undeveloped and 4 urban sites from research network sites, including Critical Zone Observatories (CZOs, http://criticalzone.org/national/), Long Term Ecological Research Network (LTER, https://lternet.edu/), and Watershed Function Scientific Focus Area (SFA, https://watershed.lbl.gov/). The 6 undeveloped sites include Shale Hills watershed (CZO, Pennsylvania) (Brantley et al., 2018), East River and Coal Creek watersheds (Colorado) (Zhi et al., 2019), Sleepers River Research Watershed (Vermont) (Armfield et al., 2018; Sebestyen et al., 2008), Hubbard Brook Experimental Forest W1 and W6 watershed (LTER, New Hampshire) (Dittman et al., 2007; LaBaugh et al., 2013). The four urban sites are Dead Run, Glyndon, Gwynnbrook, and Carroll Park (Duncan et al., 2017; Kaushal et al., 2008), all located within the Gwynns Fall Watershed (Baltimore Ecosystem Study LTER, Maryland).

Land use classification. The NAWQA sites were classified based on the percentage of major land use according to the USGS criteria (Spahr et al., 2010). Agricultural sites have $>50 \%$ agricultural land and $<=$ $5 \%$ urban land; urban sites have $>25 \%$ urban and $<=25 \%$ agricultural land; undeveloped sites have $<=5 \%$ urban and $<=25 \%$ agricultural land; all other combinations of urban, agricultural, and undeveloped land are classified as mixed. Land use in the WQW sites was compiled from multiple sources including EPA water quality reports, USGS watershed management plan, USDA watershed assessment report, and the National Land Cover Database (Hyer et al., 2016; Machesky et al., 2010; Tedesco et al., 2005). Out of the 228 sites, the numbers of Agriculture, Mixed, Undeveloped, and Urban sites are 61, 78, 49, and 40, respectively.

Concentration-discharge (C-Q) data analysis and estimation of shallow and deep water concentrations. A variety of metrics have been proposed for characterizing export regimes, including load-discharge relationship, temporal inequality of load and discharge, and various forms of concentration and discharge relationships (Basu et al., 2010; Jawitz \& Mitchell, 2011; Thompson et al., 2011; Zhang, 2018). Here we used the power law form of $C=a Q^{b}$, a common form for cross-site comparison (Godsey et al., 2009; Herndon et al., 2015). Here $C$ is the nitrate concentration, $Q$ is discharge, and $a$ and $b$ are fitting parameters with $b$ quantifying the C-Q slopes. For the NAWQA sites with monthly data, C-Q slopes were calculated using all available paired daily data over multiple years. Duplicate and incomplete records and concentrations below the Method Detection Limit (MDL) of $0.01 \mathrm{mg} / \mathrm{L}$ were excluded for C-Q fitting (Nolan and Stoner, 2000). Flow-weighted stream concentrations $\left(\mathrm{C}_{\text {stream }}\right.$ in Figures 2 and 3$)$ were calculated by dividing total nitrate load by total discharge for the entire data period.

The WQW sites have data up to 15 min frequency for multiple years (2-4 years typically). High-frequency data were aggregated to daily means of discharge and nitrate concentrations. They were then used to calculate the slope $b$ for each year so that the $b$ values were at consistent time scale as those from NAWQA. The mean and standard deviation of slope $b$ are reported in Figure 5 and 6 . In addition, these high-frequency stream data were used to infer end-member concentrations in shallow and deep waters. Shallow soil water often dominates at high flow conditions, whereas deeper base flow predominates in low flow conditions. Based on this, deep water concentrations $\left(\mathrm{C}_{\mathrm{dw}}\right)$ were estimated as the average of stream concentrations during low flows at the $5^{\text {th }}$ percentile of annual discharge. Shallow water concentrations $\left(\mathrm{C}_{\mathrm{sw}}\right)$ were estimated as the average of stream concentrations during high flows ( $95^{\text {th }}$ percentile of annual discharge). The concentration ratio $\left(\mathrm{C}_{\text {ratio }}\right)$ was calculated as $\mathrm{C}_{\text {ratio }}=\mathrm{C}_{\mathrm{sw}} / \mathrm{C}_{\mathrm{dw}}$.

Validation of shallow and deep water chemistry estimation.For shallow water concentrations, we used a recent study that compiled measured stream water and soil water concentration from 94 sites with diverse land cover (e.g., agriculture, forest, disturbed forest, grassland, urban) across the globe (Sudduth et al., 2013). To be consistent in land use classification, we grouped "forest", "disturbed forest", and "grassland" in Sudduth et al. (2013) as "undeveloped" in this work. With limited measurements of $\mathrm{C}_{\mathrm{sw}}$, we 
cannot directly compare estimated and measured $\mathrm{C}_{\mathrm{sw}}$ in individual sites. Instead, we examined whether the relationship between estimated $\mathrm{C}_{\mathrm{sw}}$ and $\mathrm{C}_{\text {stream }}$ from this study is close to the derived relationship between measured $\mathrm{C}_{\mathrm{sw}}$ and $\mathrm{C}_{\mathrm{stream}}$ from Sudduth et al. (2013). The relationships would be similar if the end-member estimation could provide a realistic estimation of $\mathrm{C}_{\mathrm{sw}}$ (Figure 4a).

For deep water chemistry, we used the National Ground-Water Monitoring Network (NGWMN), a compiled database for groundwater level and water quality (https://cida.usgs.gov/ngwmn/). Based on well location and data availability, groundwater nitrate data were retrieved from the Midwest (i.e., Minnesota, Wisconsin, Iowa, Nebraska, Illinois), New Jersey, and Florida for the maximum coverage. Based on the proximity of sites, a number of sub-regions were selected for comparing estimated vs. measured $\mathrm{C}_{\mathrm{dw}}$ (Figure S5). Within each sub-region, estimated and measured $\mathrm{C}_{\mathrm{dw}}$ were averaged and compared (Figure $4 \mathrm{~b}$ ).

Watershed reactive transport modeling. Watershed modeling was carried out using a recently developed code BioRT-Flux-PIHM, to explore the effects of subsurface vertical profile for N (Zhi et al., 2019). A base model was set up at the Conewago Creek watershed, a tributary to the Susquehanna River in the Chesapeake Bay. It drains an area of $136 \mathrm{~km}^{2}$ and is dominated by agricultural (47\%), forested (43\%), and developed (17\%) lands. The base model reproduced the temporal discharge and the slightly flushing C-Q pattern as observed at the site (Figure S6 and S7). Monte-Carlo simulations of 500 cases were carried out to cast the base model results to broader conditions spanning a range of $\mathrm{N}$ vertical distribution and reaction kinetics representing different land use conditions (Figure 6). We then derived a general relationship for the dependence of C-Q $b$ slope on the ratio of shallow versus deep water concentration $\left(\mathrm{C}_{\mathrm{sw}} / \mathrm{C}_{\mathrm{dw}}\right)$. This simple relationship was further verified by $b$ values estimated based on stream water chemistry from 81 sites, and a few intensively monitored sites with detailed soil and groundwater measurements. Other details of model setup and calibration, and Monte-Carlo simulation are in the Supporting Information (SI).

\section{RESULTS}

Nitrate concentrations under different land uses. Nitrate data from 228 sites across the contiguous United States were analyzed (See Detailed Methods). This includes 147 sites from the National Water-Quality Assessment (NAWQA) project (Spahr et al., 2010) and 71 sites from the Water Quality Watch (WQW) (https://waterwatch.usgs.gov/wqwatch/) within the United States Geological Survey (USGS), and 10 sites from intensively monitored sites via research networks in the U.S.. Higher stream nitrate concentrations generally cluster in the Midwestern "Corn Belt" that is dominated by agricultural and mixed lands, whereas undeveloped and urban sites consistently have lower nitrate concentrations (Figure 2). The soil water and groundwater nitrate concentrations (Figure S1, 81 sites) estimated from stream concentrations generally follow the spatial pattern of stream nitrate concentration, indicating the penetration of nitrate into deeper groundwater.

Statistical boxplot (Figure 3) confirmed that stream nitrate concentrations (median and mean in mg/L) decrease from Agriculture $(3.2,4.0)$, to Mixed $(1.4,2.5)$, to Urban $(0.58,0.94)$, and to Undeveloped (0.16, $0.26)$. The deep water concentrations $(\mathrm{mg} / \mathrm{L})$ have a sequence similar to stream water concentrations, decreasing from Agriculture $(2.9,3.0)$ to Urban $(1.2,1.7)$ to Undeveloped land $(0.13,0.25)$. These values are close to the national median groundwater concentration $(\mathrm{mg} / \mathrm{L})$ of agricultural land (3.1), urban land (1.4), and major aquifer wells (0.56) (Burow et al., 2010). Compared to pristine sites, agriculture and urbanization have elevated nitrate level by 3 to 20 times. Agriculture and Mixed lands also show much higher shallow water concentrations $\left(\mathrm{C}_{\mathrm{sw}}\right)$ compared to deep water concentrations $\left(\mathrm{C}_{\mathrm{dw}}\right)$, whereas Undeveloped lands exhibit the opposite trend. The Urban sites are the only land type with $\mathrm{C}_{\mathrm{dw}}>\mathrm{C}_{\mathrm{sw}}$. Stream and soil water concentrations correlate strongly with the percentage of agricultural land with the correlation $\mathrm{C}_{\text {stream }}=0.28 \mathrm{e}^{0.031 \times \% \mathrm{Ag}}$ $\left(\mathrm{R}^{2}=0.54\right)$ and $\mathrm{C}_{\mathrm{sw}}=0.35 \mathrm{e}^{0.034 \times \% \mathrm{Ag}}\left(\mathrm{R}^{2}=0.54\right)$, respectively. Deep nitrate concentrations do not correlate well with agricultural area fraction $\left(\mathrm{R}^{2}=0.25\right)$, indicating that other factors might be important in determining nitrate in deep water (Figure S3).

Estimated versus measured concentrations in shallow and deep waters. Co-located measurements of stream, soil water, and groundwater concentrations are rare, except in a few intensively measured sites. 
End-member estimation such as hydrograph separation and chemical mixing analysis are often used to quantify baseflow and quick flow contribution (Raffensperger et al., 2017) and solute concentrations in endmembers (Miller et al., 2017). To validate the estimation of $\mathrm{C}_{\mathrm{sw}}$ and $\mathrm{C}_{\mathrm{dw}}$ using stream concentration at the $95^{\text {th }}$ and $5^{\text {th }}$ percentiles, we compare estimation from this work (Figure 3a and Figure S1) against literature data and the National Ground-Water Monitoring Network (NGWMN) database (see Detailed Methods). Results show that the linear relationship between $\mathrm{C}_{\text {stream }}$ and estimated $\mathrm{C}_{\mathrm{sw}}$ from this work (slope $=0.9$, $\mathrm{R}^{2}=0.94$ ) is close to the linear relationship estimated for 94 sites of diverse land uses covering 4 orders of magnitude (Sudduth et al., 2013) (Figure 4a), suggesting a strong correlation between $\mathrm{C}_{\mathrm{sw}}$ and $\mathrm{C}_{\text {stream }}$. The agricultural sites dominate the top right corner with high $\mathrm{C}_{\mathrm{sw}}$ and $\mathrm{C}_{\text {stream }}$. Comparison of estimated and measured groundwater concentrations as a proxy for $\mathrm{C}_{\mathrm{dw}}$ exhibits a consistent spatial pattern from closely located sites in the NGWMN (Figure S5). Most estimated and measured $\mathrm{C}_{\mathrm{dw}}$ falls on the 1:1 line in Figure $4 \mathrm{~b}$, indicating a close match (Figure $4 \mathrm{~b}$ ). The relatively large error bars of measured $\mathrm{C}_{\mathrm{dw}}$ may be due to varying sampling depths in different wells.

Nitrate export patterns under different land uses. Figure 5 (and Figure S2) showed that although different export patterns (i.e., multiannual scale $\mathrm{C}-\mathrm{Q}$ relationship) occur in all land use conditions, more agricultural sites have high $b$ values and more urban sites have low $b$ values. In other words, flushing patterns dominate in agriculture and mixed lands. This challenges the existing perception that agricultural lands typically have chemostatic or biogeochemical stationary patterns (Basu et al., 2010; Basu et al., 2011; Thompson et al., 2011). Diamond and Cohen (2018) also found that a greater agricultural land cover was not associated with chemostasis patterns. For urban watersheds, chemostasis and dilution patterns are most commonly observed but flushing also occurs. In pristine sites, both chemostasis and flushing patterns are common.

Concentration contrasts in shallow and deep waters drive C-Q patterns. To explain nitrate export patterns under different land use conditions, we resort to a recently-developed, process-based watershed reactive transport model BioRT-Flux-PIHM (Zhi et al., 2019) to explore the drivers of C-Q patterns. The model was set up first to reproduce hydrological and nitrate data in Conewago Creek, a watershed with $47 \%$ agricultural land in the Chesapeake Bay. The model has three major water components contributing to the stream: surface runoff, soil water, and deep water. The shallow water combines surface runoff and shallow soil interflow water, and the deep water is the groundwater that interacts with the stream. Annually the shallow and deep water comprise $80.7 \%$ and $19.3 \%$ of the total discharge, respectively, although at daily scale the deep water can vary from $1 \%$ under dry conditions to $99 \%$ during large storm events. The hydrology aspect of the model captured the general trend that shallow water dominates stream discharge at high flow and deep water predominates at low flow. The model reproduced the daily discharge dynamics that was highly responsive to precipitation, as well as daily concentration range, temporal trends, and C-Q patterns (Figure $\mathrm{S} 6$ ). The slope $b$ from the $\mathrm{C}-\mathrm{Q}$ data is 0.13 , and the annual concentrations of shallow water $\left(\mathrm{C}_{\mathrm{sw}}\right)$ and deep water $\left(\mathrm{C}_{\mathrm{dw}}\right)$ were 3.8 and $2.1 \mathrm{mg} / \mathrm{L}$, respectively, yielding a $\mathrm{C}_{\text {ratio }}$ of 1.8 .

To cast the model to broader conditions, 500 Monte-Carlo simulations were run using the hydrology and reaction kinetic conditions from the base case and variable soil $\mathrm{N}$ concentrations that yield the representative range of shallow and deep waters in the four land use types in Figure 1. The model reproduced the range of soil water and groundwater concentrations and $\mathrm{C}_{\text {ratio }}$ in Figure 2 (see Methods and Figure S7 for C-Q relationships in four cases representing four different land uses). In each simulation case, the model outputs of concentrations and discharge were used to calculate $b$ values and the annual average $\mathrm{C}_{\mathrm{sw}}, \mathrm{C}_{\mathrm{dw}}$, and $\mathrm{C}_{\text {ratio }}$ (Figure S8). Model results from the 500 cases (overlapping gray circles, Figure 6) collapse to an "S" shaped curve $\left(b=\frac{\delta_{b} C_{\text {ratio }}}{C_{\text {ratio, } 1 / 2+C_{\text {ratio }}}}+b_{\text {min }}\right)$ that illustrates the consistent dependence of $b$ values on $\mathrm{C}_{\text {ratio }}$, where $\delta_{b}=1.66$ is the difference between maximum $b\left(b_{\max }=0.73\right)$ and minimum $b\left(b_{\min }=-0.93\right)$ and $C_{\text {ratio, } 1 / 2}=0.80$ is the concentration ratio when $b=\frac{1}{2}\left(b_{\max }+b_{\min }\right)$. This modeled "S" curve explained the $b$ values from 81 sites with available $\mathrm{C}_{\text {ratio }}$ data. The curve shows that most agricultural and mixed lands have high $b$ values whereas urban and undeveloped lands have lower $b$ values.

\section{DISCUSSION}


The significance of $\mathbf{N}$ distribution and processes in the shallow and deep subsurface. Figure 6 suggests that the subsurface $\mathrm{N}$ concentration contrast (or $\mathrm{C}_{\text {ratio }}$ ) arising from different land uses predominantly control export patterns. The representatives of shallow and deep waters, such as soil and groundwater, have been shown before to correlate well with stream nitrate concentration across different land uses (Sudduth et al., 2013). The export pattern dependence on concentration contrast echoes the decades-long End Member Mixing Approach (EMMAS) that uses end-member concentrations to infer stream water chemistry (Hooper et al., 1990). The spatial data synthesis across the U.S. continent from this work enables the generalization of this idea across diverse climate, geology, and land use conditions. The physics-based watershed reactive transport modeling facilitates the derivation of the general equation that can be used to estimate export patterns based on streamflow concentrations or measured shallow and deep water concentrations.

These shallow versus deep physical contrasts originate from chemical and physical weathering in pristine sites (Brantley et al., 2017). In urban and agriculture sites, these contrasts arise from human engineering efforts with tile drains, impervious surfaces, and water pipes that modify environments (Grimm et al., 2008). The concentration differences in shallow and deep waters arise not only from different subsurface distribution of $\mathrm{N}$ source but also from different processes. In agricultural lands, nitrate concentrations in shallow waters are high not only because abundant $\mathrm{N}$ sources leach nitrate; it is also because denitrification is limited with the presence of abundant $\mathrm{O}_{2}$. In deeper groundwater, with limited $\mathrm{O}_{2}$, denitrification can occur and reduce nitrate (Kolbe et al., 2019).

Under broad conditions, the relative magnitude of shallow versus deep water concentrations may hinge on soil properties and geologic structure. These subsurface structures determine shallow and deep connectivity, recharge and water table depth (Brantley et al., 2017), as well as local biogeochemical conditions (e.g., anoxic condition, organic carbon availability) that control the extent of denitrification and nitrate removal (Kolbe et al., 2019; Tesoriero et al., 2015). Miller et al. (2017) showed that nitrate export exhibits a dilution pattern in Tomorrow River, a site with permeable sand and gravel, but a flushing pattern in Duck Creek with low-permeability clayey soil clayey soils developed from glacial tills. The overwhelming convergence toward high $b$ values in agriculture lands, however, indicates that the concentration contrasts in shallow versus deep waters are the predominant control of export patterns.

In urban watersheds, we observe varied export patterns and a large number of sites have higher concentrations in deep water compared to shallow water. This is possibly caused by underground leaky sewage and pipes that can contaminate groundwater and surface water (Divers et al., 2013; Lerner et al., 1999; Pennino et al., 2016). A large number of urban watersheds also exhibit chemostatic patterns, potentially due to the co-occurrence of both shallow $\mathrm{N}$ sources (e.g., lawn fertilizer, pet waste, atmospheric deposition, automobile emission) and deeper underground input from buried sewage and septic systems. Kaushal et al. (2014) and Newcomer Johnson et al. (2014) suggest that urban N export can be influenced by the degree of hydrologic connectivity associated with impervious surface, stormwater infrastructure and sewage pipe, and stream restoration. Point source discharge from wastewater treatment plant (WWTP) can also increase nutrient loading (Luthy et al., 2015), potentially contributing to varied export patterns. In arid and semiarid regions with small urban streams, high nitrate concentration from WWTP can dominate the base flow at the dry time and become diluted under high flow conditions, resulting in dilution pattern (Marti et al., 2010). In fact, urban watersheds are complicated as the groundwater-soil-surface water interactions are modified by the level of urbanization and management, and non-point sources from leaky infrastructure and chronic groundwater contamination (Kaushal \& Belt, 2012).

Limitations, simplifications, and uncertainties . The conceptual model in Figure 1 and the general b equation in Figure 6 emphasize two end members in shallow and deep zones and are meant to build a simple relationship between export patterns and major components of water contributing to the stream. Here we lump the waters into shallow and deep waters components to illustrate the first-order control. Such simplification is often necessary in practice. In urban watersheds, for example, the impervious surface often contributes to large surface runoff in storms. Surface runoff however typically dominates as short pulses in early stages of storm events often resulting in an overall limited contribution of surface runoff to annual 
discharge (e.g., $11 \%$ by Pellerin et al. (2008). These temporarily large contributions are followed by rapid subsurface flow (via underground stormwater pipes) with much longer duration. Field studies typically have incomplete information (e.g., hydrograph separation, isotopic signature) of contributing flow paths. It is therefore often necessary to lump different water sources into major compartments (Barnes \& Raymond, 2010), in order to capture average behaviors.

With its simplicity, the model does not take into account specifics of individual sites, which can lead to deviations from the $\mathrm{b}$ curve in Figure 6. For example, in some places, $\mathrm{N}$ is distributed and processed in a way that demands more than two end members (Cowie et al., 2017; Miller et al., 2017). The model also does not explicitly account for $\mathrm{N}$ removal in streams. Instream removal depends on a wide variety of parameters including local climate and seasonality, landscape structure (e.g., topography, hyporheic zone), and biogeochemical conditions (e.g., nitrate legacy, stream carbon source) (Dodds et al., 2002; Hill, 1996; Mulholland et al., 2008; Vidon \& Hill, 2004). Significant instream N removal can lead to underestimation of $\mathrm{C}_{\mathrm{sw}}$ and $\mathrm{C}_{\mathrm{dw}}$ but to a different extent. As $\mathrm{C}_{\mathrm{sw}}$ is estimated under high flow conditions where instream $\mathrm{N}$ removal is often not efficient, it may not be heavily influenced by instream processes (Dodds et al., 2002). The estimation of deep water concentrations however is based on low flow conditions where instream $\mathrm{N}$ removal can be highly effective such that $\mathrm{C}_{\mathrm{dw}}$ may be underestimated. This possible different extent of underestimation can shift $\mathrm{C}_{\mathrm{ratio}}\left(=\mathrm{C}_{\mathrm{sw}} / \mathrm{C}_{\mathrm{dw}}\right)$ and $\mathrm{b}$ values to higher values, moving data points toward the top right end of the $\mathrm{d} b$ curve. This may be the reason that some data points from $\mathrm{Ag}$ and Mixed fall in the right-hand side of the $\mathrm{b}$ curve in Figure 6 .

Inferring shallow and deep water chemistry from stream chemistry. This study indicates that we can infer shallow and deep water chemistry from streamflow chemistry under different flow regimes. This is important as detailed subsurface characterization and concentration measurements are often limited to only a few long-term monitoring sites in developed countries (Brantley et al., 2018; Gran et al., 2019), although we often claim an era of "big data". As shown in Figure 6, few intensively measured watersheds have both soil water and groundwater chemistry measurements. The extrapolation of shallow and deep water chemistry from high flow and low flow stream chemistry therefore enables estimation of water chemistry (without digging holes in the ground) to infer possible export patterns and loads. This approach can be applied not only for nitrate, but also for other solutes in general.

$\mathbf{N}$ export under changing climate. The agriculture sites have increased nitrate concentrations in shallow and deep waters by 15-20 times and 9-16 times, respectively, compared to undeveloped sites (Figure 3a). In fact, extensive tile drainage networks in agricultural lands (e.g., $80 \%$ of the landscape in the Midwest) shortcut the shallow water directly to stream, lowers water table (Blann et al., 2009; King et al., 2015). In effect, these draining tiles decrease vertical connectivity to deeper aquifers (Association, 2018) and therefore increase concentration contrasts between shallow water (e.g., soil water and tile drainage water) and deep groundwater, inducing pronounced flushing patterns (Figure 6). The flushing pattern indicates that export is sensitive to large hydrological events such as flooding, which has been predicted to intensify as the pace of climate change accelerates (Prein et al., 2017).

On the other hand, if high nitrate in shallow water is redirected more to the deeper subsurface via higher vertical connectivity, the water will reroute through longer flow paths, enhancing transformation via denitrification and nitrate removal (Kolbe et al., 2019). The extent of such transformation will depend on local conditions. The longer and slower groundwater flow paths however will also lead to decade-to century-scale time lags between anthropogenic N inputs and riverine outputs (Sebilo et al., 2013; Van Meter \& Basu, 2015). This can present significant challenges for balancing nitrogen budget (e.g., the 'missing' $\mathrm{N}$ in mass-balance) (Boyer et al., 2002) and management effectiveness (e.g., land-use management, N-loading reduction) (Sebilo et al., 2013; Van Meter et al., 2017). In addition, this downward $\mathrm{N}$ flux also raises tantalizing questions about long-term subsurface structure and functioning. How and how much do these man-made, high nutrient levels elevate carbon effluxes (Zamanian et al., 2018), accelerate weathering processes, and alter watershed functioning (Kaushal et al., 2013; Perrin et al., 2008)? These broader earth system responses can have far-reaching impacts on carbon and nutrient cycles at the global scale. 


\section{Acknowledgments}

This study was supported by the U.S. Department of Energy (DOE) Subsurface Biogeochemical Research (SBR) program (DE-SC0016221) and the Penn State Institute of CyberScience.

Figures in the main text
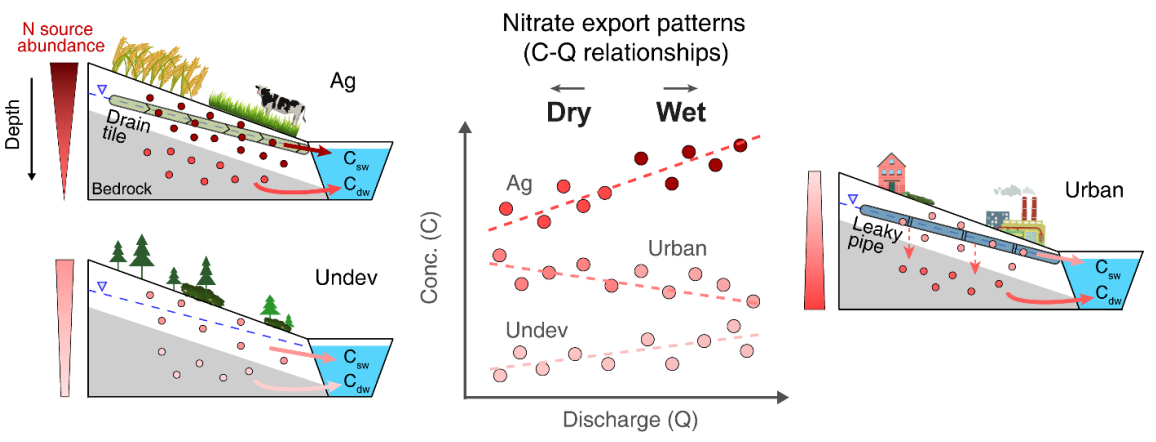

Figure 1 . A conceptual figure and hypothesis about nitrate export patterns, exemplified in ConcentrationDischarge (C-Q) relationship under different land use conditions (i.e., Ag = Agriculture, Undev = Undeveloped, and Urban). Triangle wedges at the left of each hillslope describe the depth profile of $\mathrm{N}$ abundance with dark and light red represents high and low N abundance, respectively. Here we define two "loose" end-members: the "shallow" water (from, for example, surface runoff, shallow soils, or shallow pipes) and the "deep" water (e.g., from deeper zones such as groundwater). Stream water is often dominated by shallow water under high flow conditions and by deep water under low flow conditions. We propose the shallow versus deep hypothesis: nitrate concentration contrasts in shallow water $\left(C_{s w}\right)$ and deep water $\left(C_{d w}\right)$ drive the export patterns. If this hypothesis is true, we expect higher concentrations in shallow water in agricultural lands, leaning toward a flushing pattern. In contrast, in urban watersheds, concentrated nutrients accumulated in leaky pipes in deeper subsurface are often higher than shallow, rapid runoff on impervious surfaces, possibly leaning toward a dilution pattern. Nitrogen in forests and pristine sites can come from the decomposition of organic matters in shallow soils and leaching from N-containing rocks in deeper zones. They are often tightly cycled with very low concentrations. These characteristics can lead to diverse patterns 

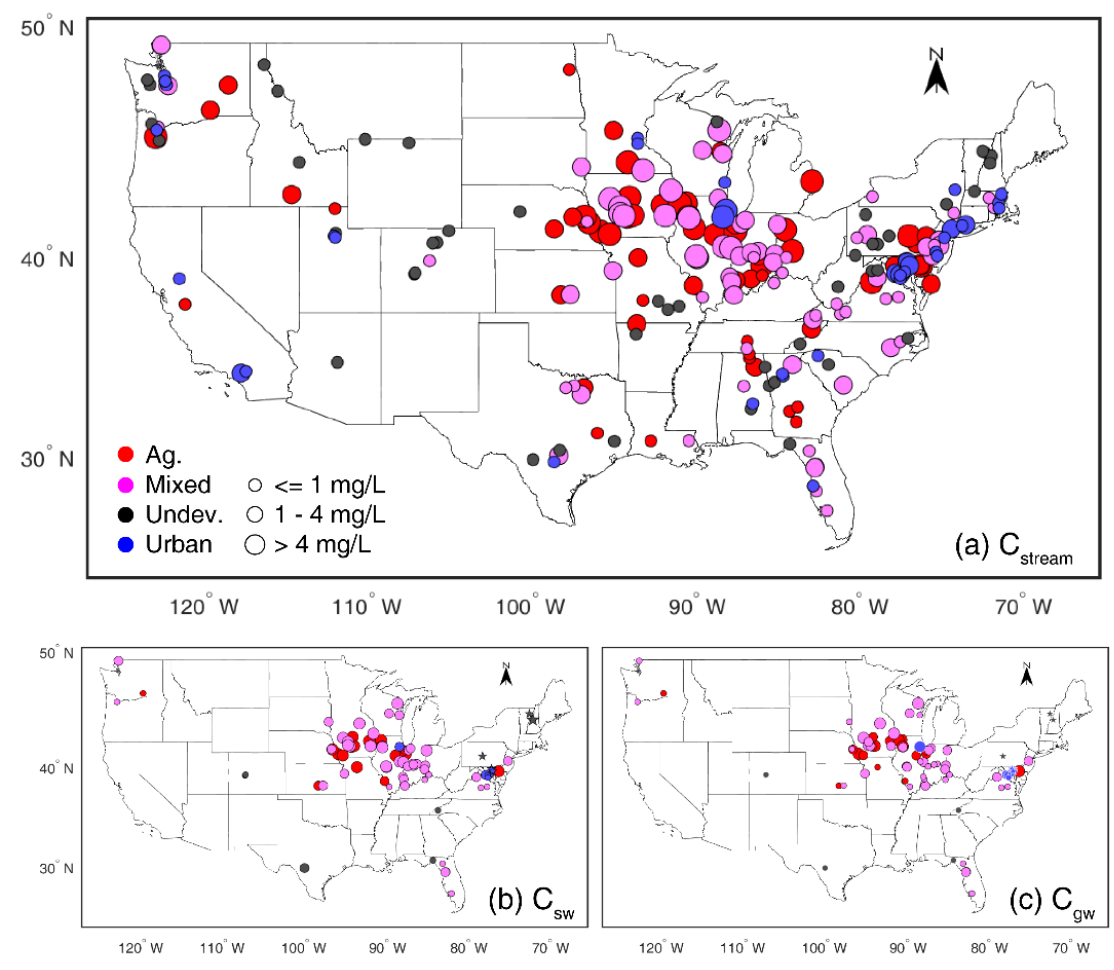

Figure 2. The spatial pattern of stream nitrate $\left(\mathrm{NO}_{3}-\mathrm{N}\right)$ concentration under Ag (agriculture, 61 sites), Mixed ( $\mathrm{Ag}+$ other land use, 78 sites), Undev (Undeveloped, pristine, 49 sites), and Urban (40 sites) conditions. Please refer to Detailed Methods for the classification of land uses. Compared to undeveloped sites, agricultural lands generally have elevated stream water concentrations by more than one order of magnitude.
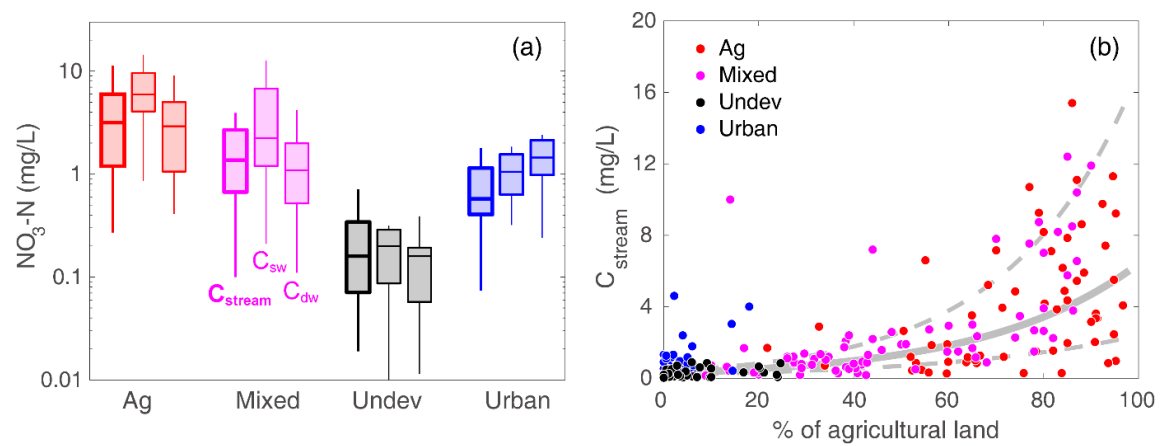

Figure 3. Nitrate $\left(\mathrm{NO}_{3}-\mathrm{N}\right)$ concentrations: (a) Statistics of stream $\left(\mathrm{C}_{\text {stream }}\right.$, left box $)$, shallow water $\left(\mathrm{C}_{\mathrm{sw}}\right.$, middle box), and deep water (often groundwater, $\mathrm{C}_{\mathrm{dw}}$, right box) under different land use conditions. The $\mathrm{C}_{\text {stream }}$ was the direct field measurement from 228 sites while $\mathrm{C}_{\mathrm{sw}}$ and $\mathrm{C}_{\mathrm{dw}}$ were estimated and/or measured end-member concentrations from 81 sites. The central line in each box indicates the median, and the bottom and top edges are the $25^{\text {th }}$ and $75^{\text {th }}$ percentiles, respectively. The whiskers extend to the most extreme data points not considered outliers (not shown). Outliers are defined as data points more than 1.5 interquartile ranges (IQR, Q3-Q1) below the first quartile (Q1) or above the third quartile (Q3), i.e., < Q1-1.5 $\times$ IQR or $>\mathrm{Q} 3+1.5 \times \mathrm{IQR}$. (b) $\mathrm{C}_{\text {stream }}$ as a function of agricultural land cover. The solid gray line is the fit equation 
$\mathrm{C}_{\text {stream }}=0.28 \mathrm{e}^{0.031 \times \% \mathrm{Ag}}\left(\mathrm{R}^{2}=0.54\right)$, and the dashed gray lines are confidence interval at $99.9 \%$, with upper and lower bound equations of $\mathrm{C}_{\text {stream }}=0.39 \mathrm{e}^{0.038 \times \% \mathrm{Ag}}$ and $\mathrm{C}_{\text {stream }}=0.20 \mathrm{e}^{0.025 \times \% \mathrm{Ag}}$, respectively.
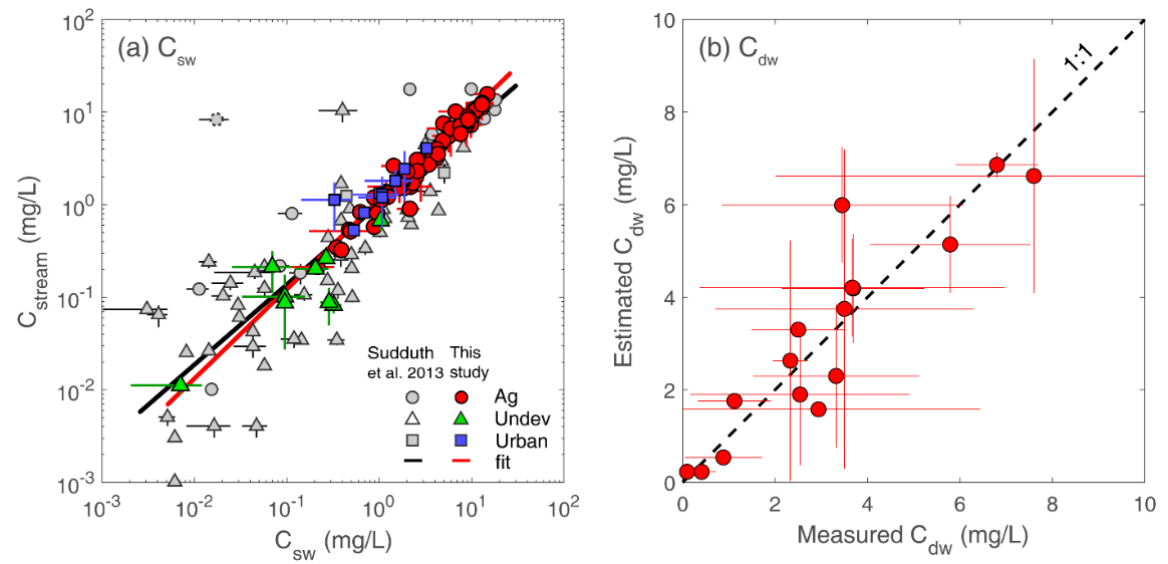

Figure 4. Validation of estimated $\mathrm{C}_{\mathrm{sw}}$ and $\mathrm{C}_{\mathrm{dw}}$ (this study). (a) A linear relationship (red line with slope $=0.95$ and $\mathrm{R}^{2}=0.94$ ) derived from estimations in this work (colored markers), compared to the linear relationship (black line, slope $=0.83, \mathrm{R}^{2}=0.70$ ) from measurements (gray markers) compiled in Sudduth et al. (2013). The dotted gray circle at the top left corner is an outliner and was excluded from data fitting. The similar slope and correlation indicate that $\mathrm{C}_{\mathrm{sw}}$ estimated from stream chemistry approximates measured $\mathrm{C}_{\mathrm{sw}}$. The $\mathrm{C}_{\text {stream }}$ from this study are flow-weighted concentrations calculated by dividing annual nitrate load by annual discharge. (b) Estimated $\mathrm{C}_{\mathrm{dw}}$ from this work vs. measured groundwater concentration (as a proxy for $\mathrm{C}_{\mathrm{dw}}$ ) from the National Ground Water Monitoring Network. The measured groundwater concentrations were averaged for close by regions (Figure S5). Most symbols fall close to the 1:1 line, indicating estimated $\mathrm{C}_{\mathrm{dw}}$ can be used to approximate groundwater concentration. Error bars are for one standard deviation in nearby regions.

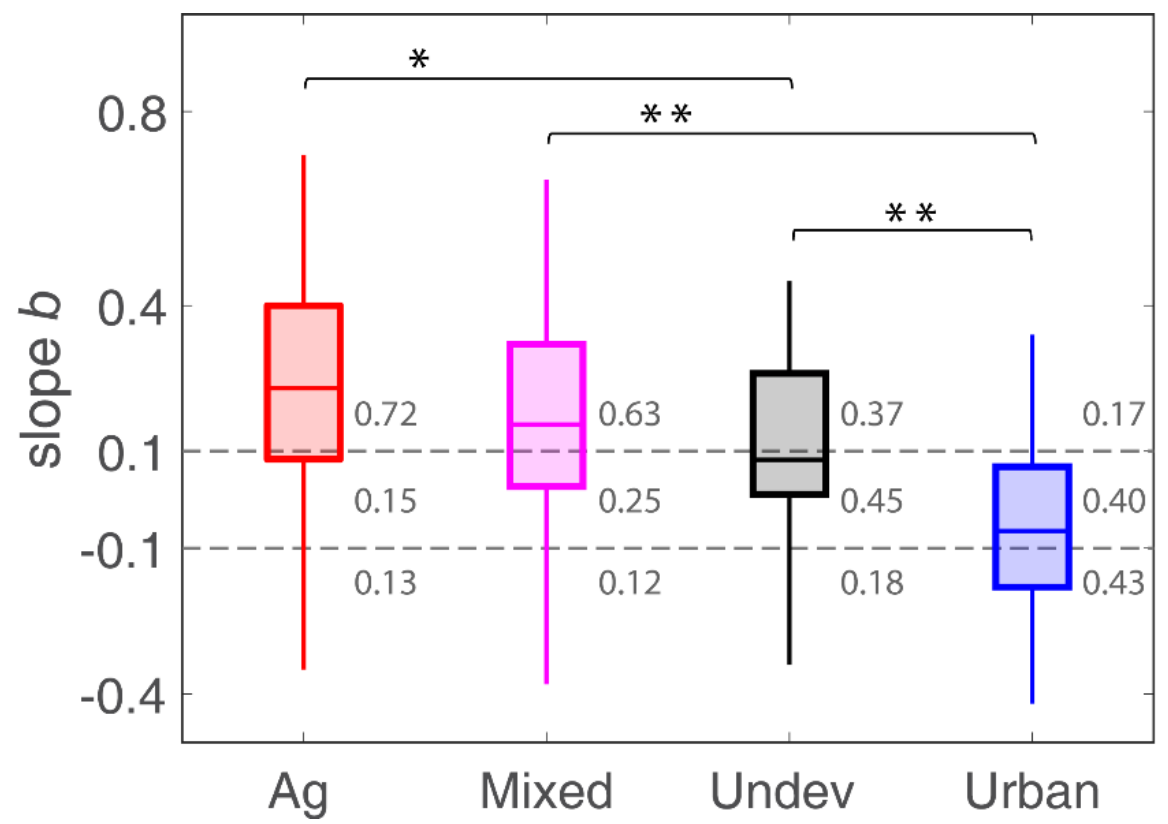

Figure 5. Boxplot of slope $b$ under different land use conditions. The slope $b$ was calculated from multiple 
years of low-frequency concentration and discharge data and high-frequency data averaged to daily values so the focus here is not event-based C-Q (see Detailed Methods). The gray dashed lines are thresholds separating flushing $(b>0.1)$ and dilution patterns $(b<-0.1)$ from the chemostatic pattern, using $b=0.1$ and $=0.1$ as thresholds (Herndon et al., 2015; Hoagland et al., 2017). The gray numbers are the fractions of flushing, chemostatic, and dilution patterns. Two-sample $t$-tests were performed for statistical analysis: the single star marker indicates statistical significance at the level of 0.05 , and the double star maker indicates statistical significance at the level of 0.01 .

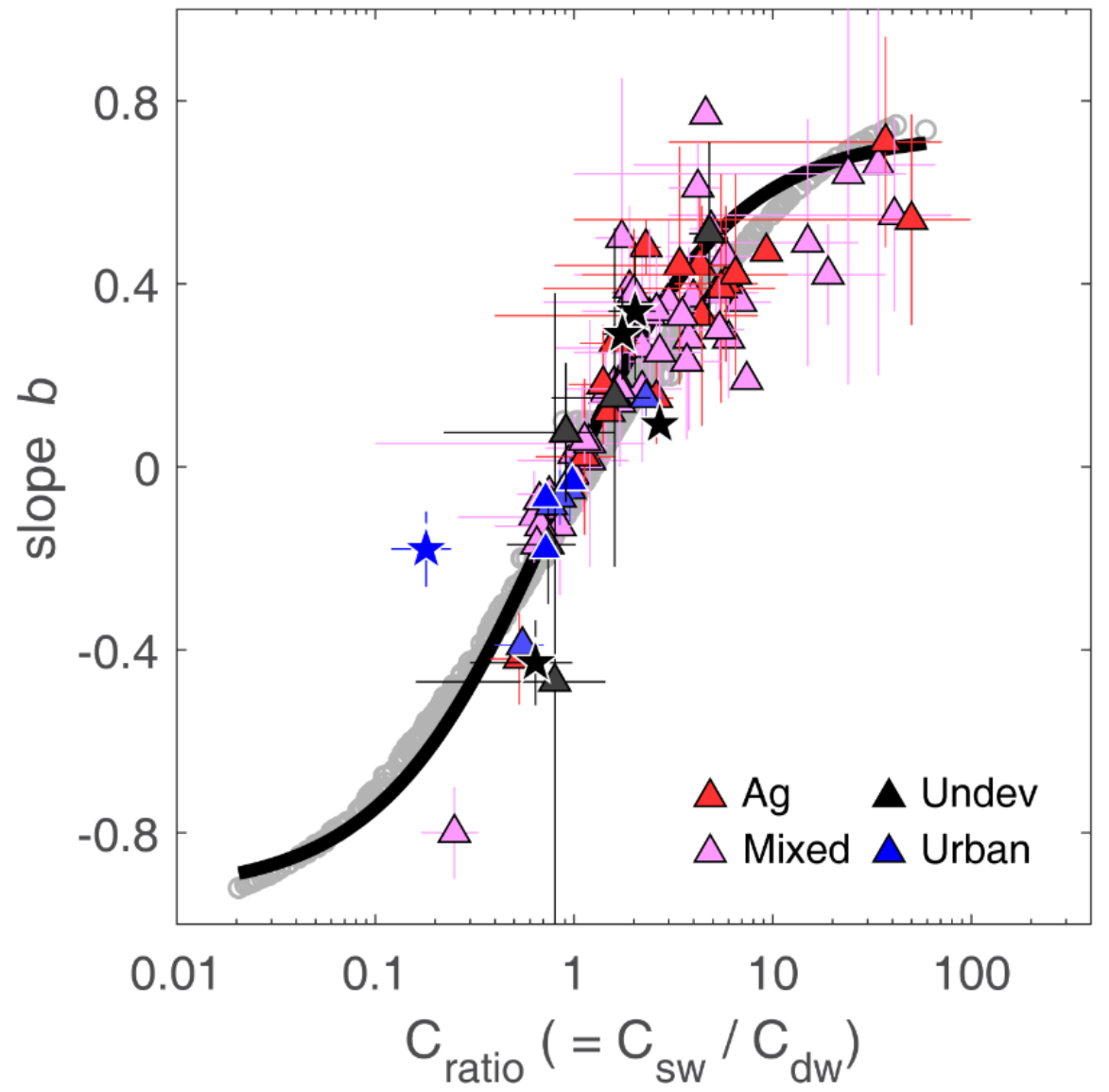

Figure 6 . The dependence of export pattern, or C-Q slopeb, on the ratio of shallow water versus deep water concentrations $\left(\mathrm{C}_{\mathrm{ratio}}=\mathrm{C}_{\mathrm{sw}} / \mathrm{C}_{\mathrm{dw}}\right)$. The gray line is an ensemble of 500 gray circles from 500 Monte-Carlo simulations under different land use conditions. Each gray circle represents one simulation with a calculated slope $b$ from simulated $\mathrm{C}$ and $\mathrm{Q}$ values and $\mathrm{C}_{\text {ratio }}$ from an annual average of simulated $\mathrm{C}_{\mathrm{sw}}$ and $\mathrm{C}_{\mathrm{dw}}$ (see Figure S8). The triangles and stars are from individual watersheds: some are based on measured stream discharge, chemistry, and soil and groundwater concentrations $\mathrm{C}_{\text {ratio }}$ (triangles), and others are based on high-frequency stream data (stars). The error bars are for one standard deviation. The black line represents the fitting equation $b=\frac{\delta_{b} C_{\text {ratio }}}{C_{\text {ratio, } 1 / 2}+C_{\text {ratio }}}+b_{\min }$, which describes the black line and the dependence of $b$ on $\mathrm{C}_{\text {ratio }}$. Here $\delta_{b}$ is the difference between maximum $b\left(b_{\max }\right)$ and minimum $b\left(b_{\min }\right)$, and $C_{\text {ratio, } 1 / 2}$ is the concentration ratio when $b=\frac{1}{2}\left(b_{\max }+b_{\min }\right)$. Here $b_{\max }=0.73$ and $b_{\min }=-0.93$, $\delta_{b}=1.66$, and $C_{\text {ratio, } 1 / 2}=0.80$. The agricultural and mixed lands cluster toward high b and $\mathrm{C}_{\text {ratio }}$ values, indicating flushing as the predominant export pattern. The urban watersheds lean toward chemostasis (near zero $b$ ) and dilution (negative $b$ ) patterns. The undeveloped watersheds cover a wide range with more flushing than dilution patterns. 


\section{Supporting Information}

- Supplementary Methods

- Supplementary Figures: 8

- Supplementary Tables: 1

\section{Supplementary Methods}

Watershed reactive transport modeling. BioRT-Flux-PIHM (BFP) augments the Flux-PIHM family code and is a recently developed reactive transport module BioRT for modeling watershed hydrological and biogeochemical processes. The model couples three modules: a multicomponent reactive transport module BioRT, the land-surface interaction module Flux for processes such as solar radiation and evapotranspiration (ET), and the surface hydrology module PIHM for hydrological processes (e.g., precipitation, infiltration, recharge, surface runoff, and subsurface flow). The model simulates both various types of abiotic and biotic reactions with different reaction kinetics and thermodynamics, including mineral dissolution and precipitation, and microbe-mediated redox reactions, ion exchange, surface complexation, and aqueous complexation. Detailed features are documented in other publications (Bao et al., 2017; Li, 2019; Li et al., 2017; Zhi et al., 2019).

Conewago Creek watershed, a tributary to the Susquehanna River in the Chesapeake Bay, was used as a model Watershed. It drains an area of $136 \mathrm{~km}^{2}$ and is low in elevation $(85-350 \mathrm{~m})$. Within a total of $47 \%$ agricultural land, many of the main stem and tributary floodplains are actively pastured (33\%) or cultivated for crop production (14\%). The rest of the watershed is mostly forested (43\%) and developed (17\%). Mean annual precipitation and temperature are $1,100 \mathrm{~mm}$ and $10.6 \mathrm{degC}$, respectively. The USGS has monitored discharge and water-quality since June 2011 near Falmouth, Pennsylvania (station ID: 01573710). Discharge record is available at the daily frequency and water quality has been measured bi-weekly.

Model setup and calibration (base case). The model was set up in a spatially implicit manner with watershed characteristics including initial water and geochemistry conditions, average soil properties, average land cover, and climate forcing (time series of temperature, wind speed, solar radiation, precipitation rate and chemistry) based on data from National Elevation Dataset, National Land Cover Database, Moderate Resolution Imaging Spectroradiometer (Leaf Area Index), and Soil Survey Geographic Database. The leaching of nitrate from various sources was parsimoniously represented as leaching from a generic soil solid N (possible fertilizers and Soil organic Matter) with the following reaction and rate law:Soil N (e.g. fertilizer, $S O M) \rightarrow \mathrm{NO}_{3}^{-}$, whereSOM is soil organic matter (e.g., plant residuals, biomass). Its rate was represented askAf $(\mathrm{Zw}) f(T) f(\mathrm{Sw})$, where $r$ is the reaction rate $\left(\mathrm{mol} / \mathrm{m}^{3} / \mathrm{s}\right) ; k$ is the rate constant $\left(10^{-9}, \mathrm{~mol} / \mathrm{m}^{2} / \mathrm{s}\right)$; and $\mathrm{A}$ is the effective surface area for nitrate leaching $\left(\mathrm{m}^{2}\right)$, which is calculated based specific surface area (SSA, $\mathrm{m}^{2} / \mathrm{g}$ ), volume fraction $\left(0.02 \mathrm{~m}^{3} / \mathrm{m}^{3}\right)$, and solid density (urea, $\left.1.34 \mathrm{~g} / \mathrm{cm}^{3}\right)$. The depth function $f\left(Z_{w}\right)=\exp \left(-\frac{Z_{w}}{b_{m}}\right)$ accounts for decreasing soil $\mathrm{N}$ concentration along with depth (Van Meter et al., 2016), where $Z_{w}$ is the water table depth $(\mathrm{m})$ and $b_{m}(0.5 \mathrm{~m})$ is a declining coefficient (Hagedorn et al., 2001; Weiler \& McDonnell, 2006). The $f(T)$ and $f\left(S_{w}\right)$ describe the rate dependence on soil temperature and moisture, respectively (Zhi et al., 2019). The $f(T)$ takes the widely used $\mathrm{Q}_{10}$-based form $f(T)=Q_{10}^{|T-20| / 10}$, where $T$ is the soil temperature $(\operatorname{deg} \mathrm{C})$ and $Q_{10}=2$ is the relative increase in reaction rates when temperature increases by $10 \operatorname{deg} \mathrm{C}$ (Hararuk et al., 2015; Zhou et al., 2009). The $f\left(S_{w}\right)$ takes the form of $f\left(S_{w}\right)=\left(S_{w}\right)^{n}$, where $n=2$ is the saturation exponent reflecting effects of soil water content on reaction (Hamamoto et al., 2010; Yan et al., 2016).

The model was calibrated based on the best-fit criteria for the Nash - Sutcliffe efficiency and by reproducing time series of discharge and C-Q pattern of stream nitrate. The calibrated hydrology parameters are in Table S1 (with most sensitive ones in bold). The porosity $\theta$ defines subsurface water storage with a larger water storage resulting in a larger baseflow and wide but low discharge peaks. The saturated hydraulic conductivity $K_{\mathrm{satV}}$ and $K_{\mathrm{satH}}$ are key parameters for recharge of infiltrated water and lateral flow to stream, influencing the magnitude and timing of discharge peaks. The van Genuchten parameters $a$ and $n$ primarily control soil water retention and therefore have strong impacts on discharge peaks (Shi et al., 2014). The 
biogeochemical calibration adjusts SSA for soil nitrate leaching reaction. The calibrated SSA is $2.2 \mathrm{~m}^{2} / \mathrm{g}$ that is similar to the reported range of 1.7 to $3.5 \mathrm{~m}^{2} / \mathrm{g}$ (Eghbali Babadi et al., 2019). Groundwater flow was estimated based on iterative calibration between discharge and stream chemistry. The model and data comparison is in Figure S6, where the calibrated model generally reproduced the dynamics of baseflow and discharge peaks and stream nitrate.

Monte-Carlo Simulations. Monte-Carlo simulation (500 cases) were carried out to cast the base model results to broader conditions representing the four land uses with varying subsurface N-containing material abundance. The conditions for the 500 simulations were randomly sampled across the uncertainty range of soil N fraction (0.01\% to 1\%) (Jurgensen et al., 2017; Shepherd et al., 2015) and groundwater nitrate concentration $\left(\mathrm{C}_{\mathrm{dw}}, 0.1\right.$ to $10 \mathrm{mg} / \mathrm{L}$, Figure $3 \mathrm{a}$ and Figure S4) while keeping all other hydrological and $\mathrm{N}$ leaching kinetic parameters the same as in the base case. As the volume fraction of soil $\mathrm{N}$ increases, the soil water concentration $\left(\mathrm{C}_{\mathrm{sw}}\right)$ also increase because more $\mathrm{NO}_{3}{ }^{-}$is leached out. These ranges covered the different land use types represented with their corresponding soil and groundwater concentration ranges (Figure S8). For each run, the C-Q slope $b$ was calculated based on the daily model output of concentration and discharge data. In parallel, annual averages of soil water and groundwater concentrations were used to calculate $\mathrm{C}_{\text {ratio }}$ used to plot the $b$ versus $\mathrm{C}_{\text {ratio }}$ in Figure 6.

In addition, four hypothetical cases for Agriculture, Mixed, Undeveloped, and Urban were simulated based on available $\mathrm{C}_{\mathrm{sw}}$ and $\mathrm{C}_{\mathrm{gw}}$ to illustrate typical nitrate export patterns under different land use conditions (Extended Data Figure 7). Similar to the conceptual diagram (Figure 1), results show that agriculturedominated land uses (i.e., Agriculture and Mixed) elevated stream nitrate levels and exhibited flushing C-Q patterns while the Urban land showed a dilution pattern. Undeveloped, pristine land was lowest in nitrate concentration yet exhibited a flushing pattern due to higher $\mathrm{C}_{\text {ratio }}\left(=\mathrm{C}_{\mathrm{sw}} / \mathrm{C}_{\mathrm{dw}}\right)$.

\section{Supplementary Figures (Figure S1 - S8)}

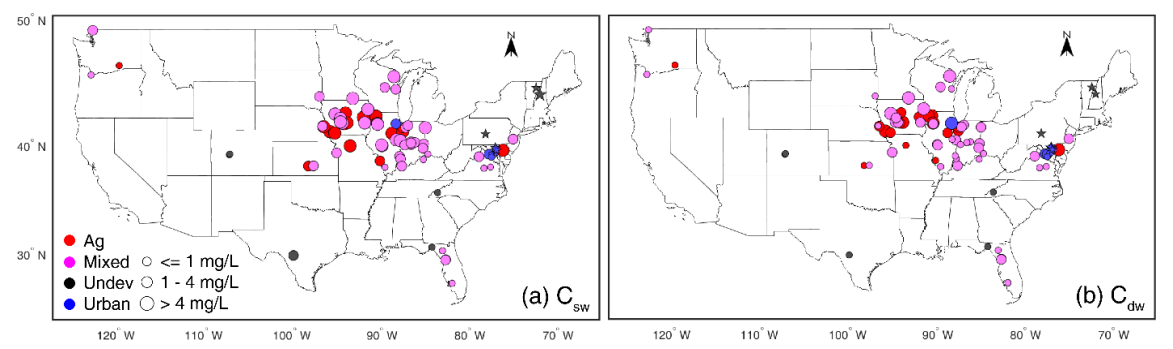

Figure S1. The spatial pattern of shallow water $\left(\mathrm{C}_{\mathrm{sw}}\right)$ and deep water $\left(\mathrm{C}_{\mathrm{dw}}\right)$ nitrate concentration under different land use conditions (81 sites). Note that filled circles are estimated end-member concentrations from high-frequency stream nitrate $\left(\mathrm{C}_{\text {stream }}\right.$, Figure 2$)$ while star markers are direct field measurements of $\mathrm{C}_{\mathrm{sw}}$ and $\mathrm{C}_{\mathrm{dw}}$ from intensively studied sites. 


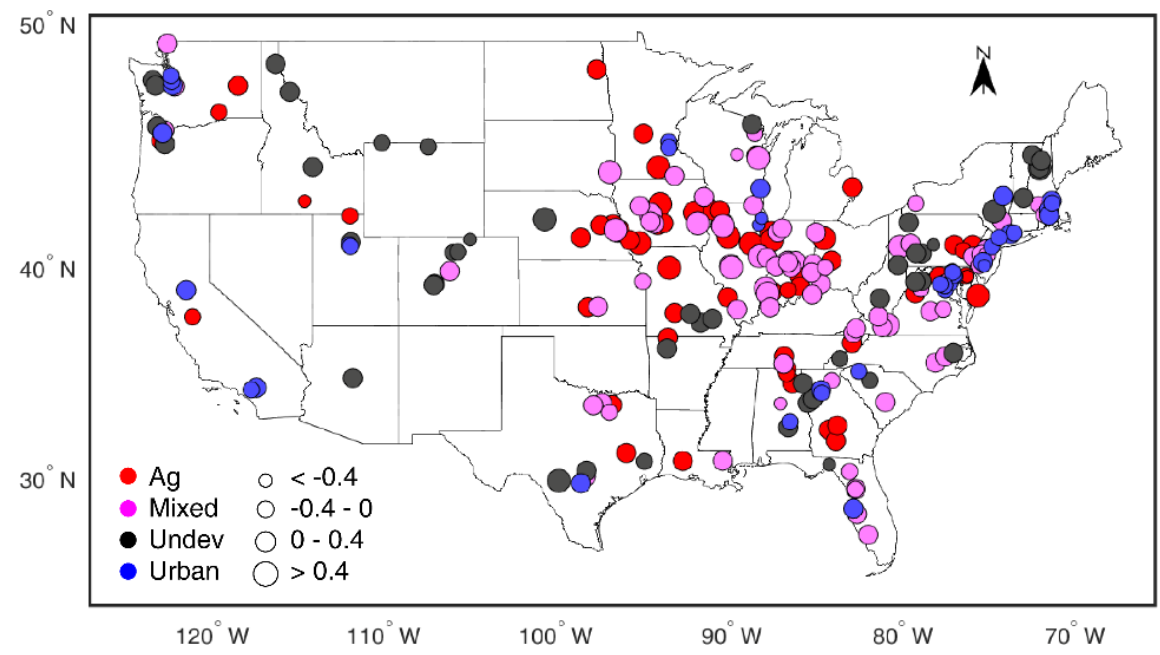

Figure S2. The spatial pattern of C-Q slope $b$ (228 sites), which was calculated by fitting the power law $C=a Q^{b}$ using all available censored data of nitrate concentration (C) and discharge (Q).
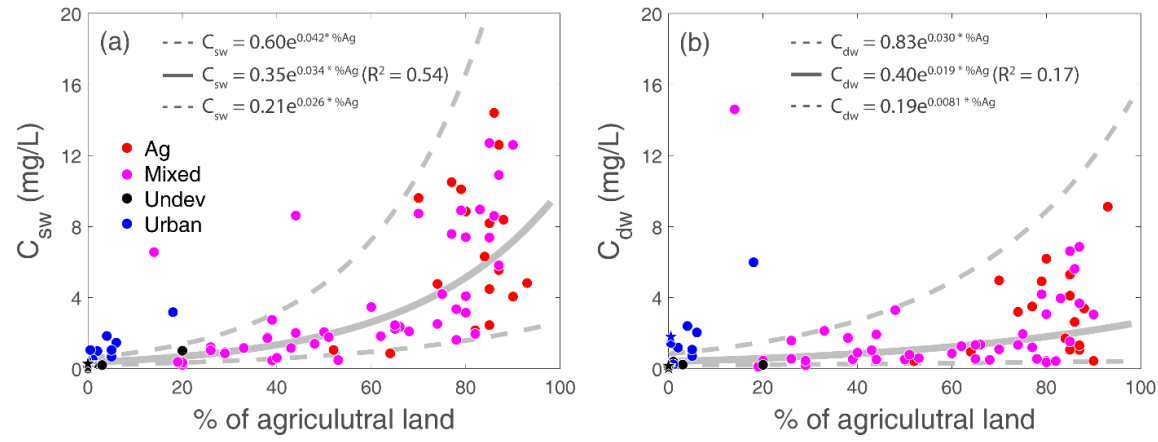

Figure S3. Shallow water $\left(\mathrm{C}_{\mathrm{sw}}\right)$ and deep water $\left(\mathrm{C}_{\mathrm{dw}}\right)$ nitrate concentration as a function of percent of agricultural land (81 sites). The solid gray line is the exponential fit while dashed lines are upper and lower bounds at the confidence interval of $95 \%$. Note that filled circles are estimated end-member concentration from high-frequency stream nitrate $\left(\mathrm{C}_{\text {stream }}\right.$, see Methods) while stars are direct field measurements of $\mathrm{C}_{\mathrm{sw}}$ and $\mathrm{C}_{\mathrm{dw}}$ from intensively studied sites. 


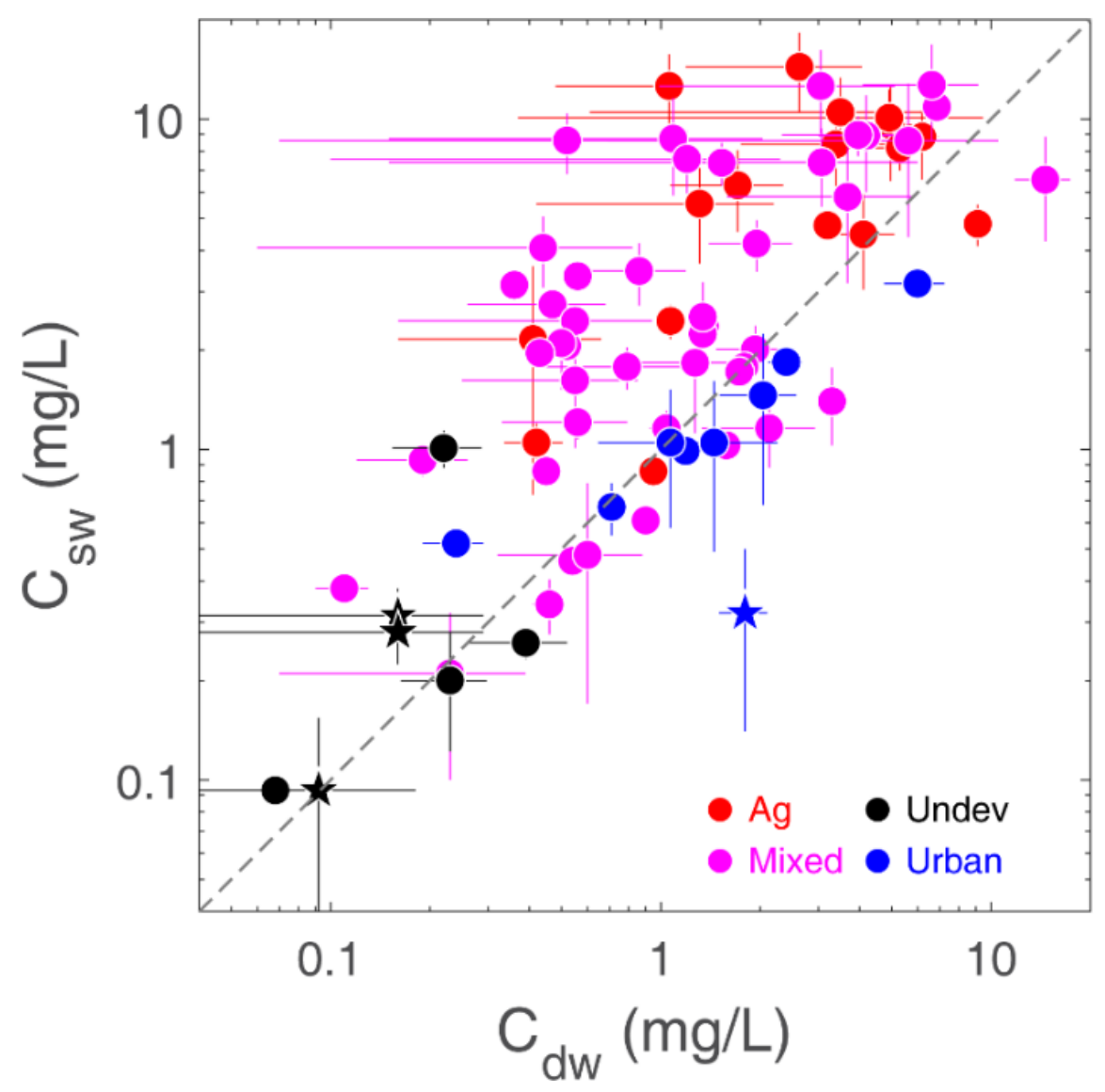

Figure S4. Shallow water $\left(\mathrm{C}_{\mathrm{sw}}\right)$ vs. deep water $\left(\mathrm{C}_{\mathrm{dw}}\right)$ nitrate concentration (Figure $\mathrm{S} 1,81$ sites). Filled circles are estimated end-member concentrations from high-frequency stream nitrate $\left(\mathrm{C}_{\text {stream }}\right)$ while stars are direct field measurements of $\mathrm{C}_{\mathrm{sw}}$ and $\mathrm{C}_{\mathrm{dw}}$ from intensively studied sites.
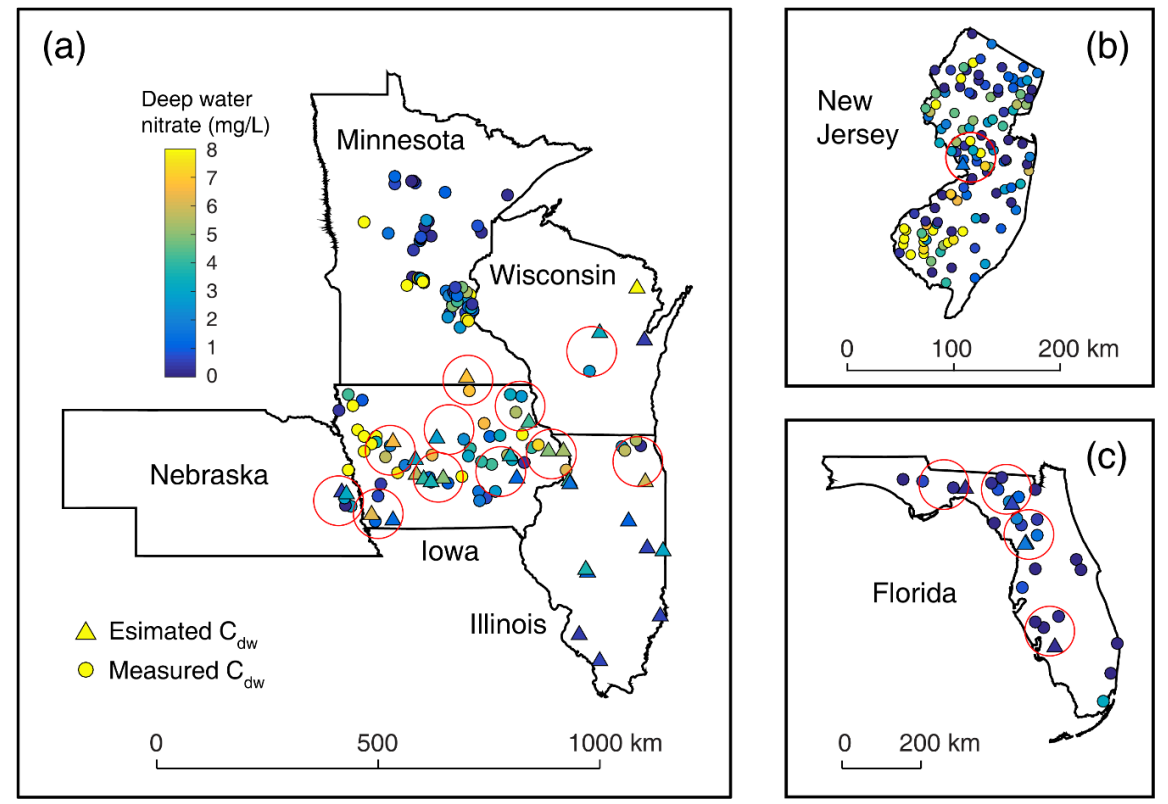
Figure S5.Validation of estimated deep groundwater nitrate concentration $\left(\mathrm{C}_{\mathrm{dw}}\right)$ against field measurements from the National Ground-Water Monitoring Network. Within each red circle, estimated and measured $\mathrm{C}_{\mathrm{dw}}$ are first averaged and then compared (results see Figure $4 \mathrm{~b}$ ). Red circles are determined by the proximity of location and data availability (i.e., at least one estimated $\mathrm{C}_{\mathrm{gw}}$ point for comparison with measurements). Iowa and Florida have more direct comparison because there are more estimated $\mathrm{C}_{\mathrm{gw}}$ points (triangle markers) located in these regions and more measured $\mathrm{C}_{\mathrm{gw}}$ points (circle markers) in proximity.

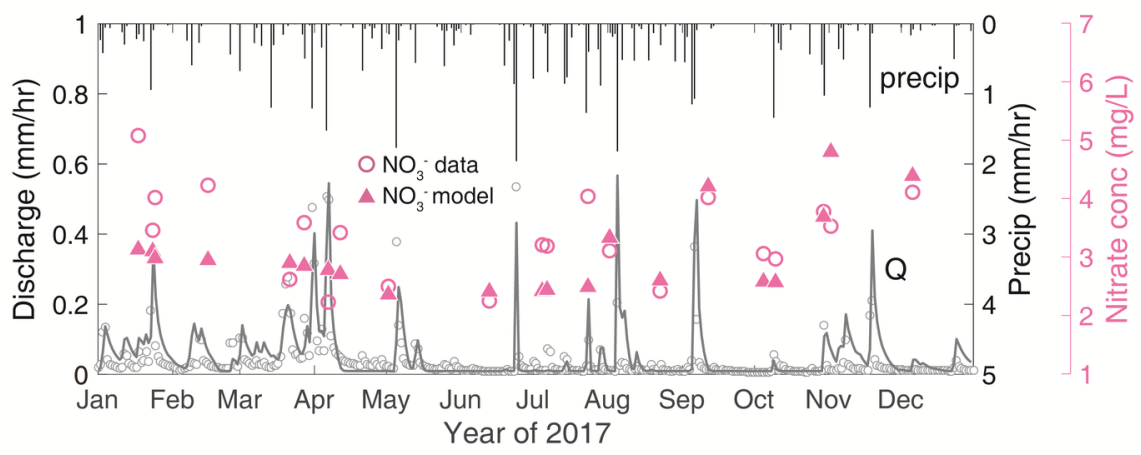

Figure S6. Water fluxes and stream nitrate in 2017: discharge (data vs. model, left-Y axis), precipitation (data, right- $1^{\text {st }}$ Y-axis), stream nitrate (data vs. model, right- $2^{\text {nd }}$ Y-axis) at Conewago Creek watershed. Annual precipitation and discharge of 2017 was $1.04 \mathrm{~m}$ and $0.47 \mathrm{~m}$, respectively, resulting in a runoff ratio of 0.45 .

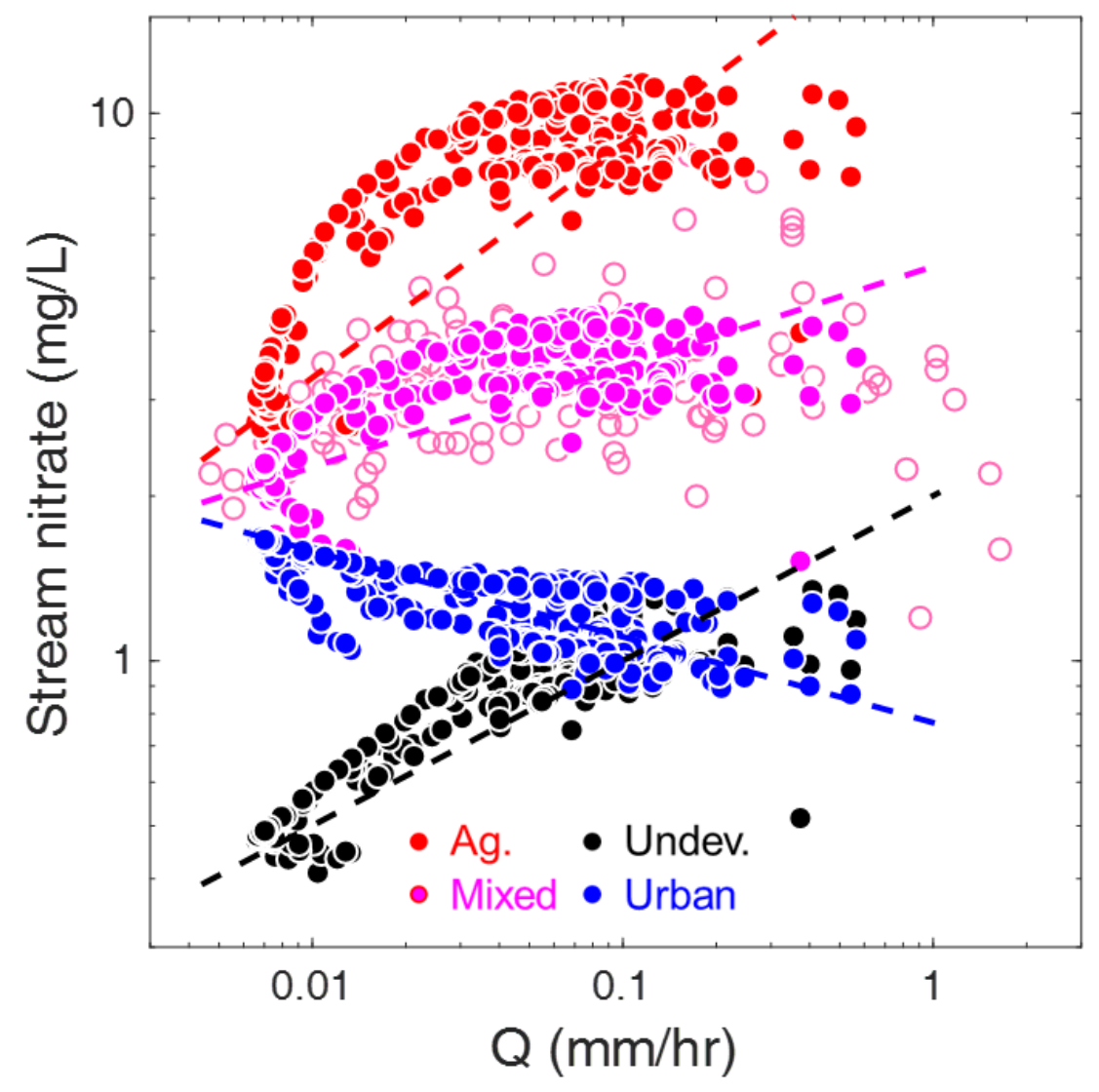


Figure S7. Modeled C-Q relationships from 4 hypothetical cases reproduced typical nitrate export patterns under Agriculture, Mixed, Undeveloped, and Urban land uses. The 4 hypothetical cases used representative soil $\mathrm{N}$ distribution to reproduce measured shallow water $\left(\mathrm{C}_{\mathrm{sw}}\right)$ and deep water $\left(\mathrm{C}_{\mathrm{dw}}\right)$ nitrate under each land use condition (Figure 3). All colored dots are from models. Open pink circles are measured stream nitrate data measured from Conewago Creek watershed. Dashed lines are C-Q fits for each model case.

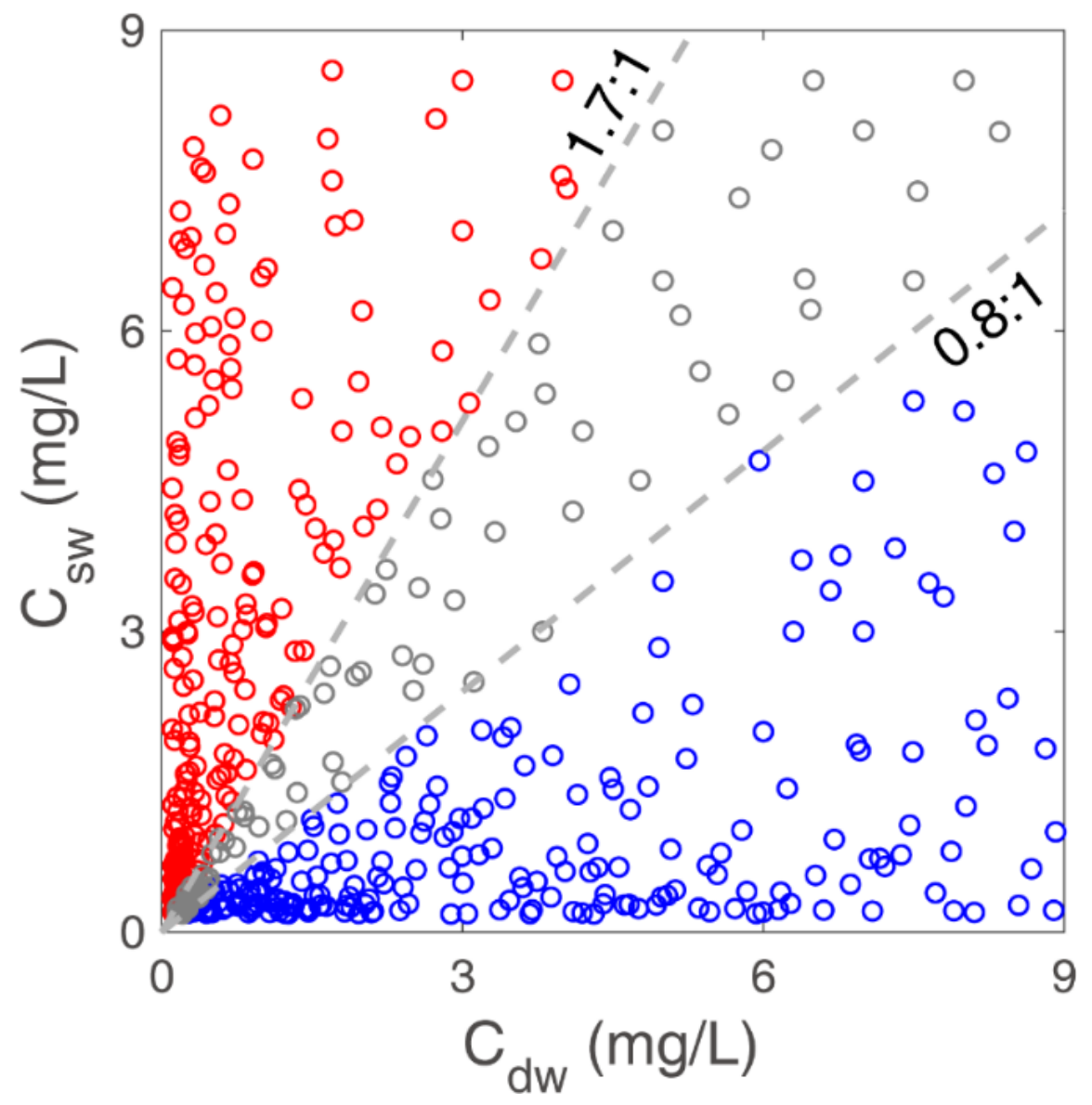

Figure S8. The annual average of shallow water $\left(\mathrm{C}_{\mathrm{sw}}\right)$ versus deep water $\left(\mathrm{C}_{\mathrm{dw}}\right)$ nitrate concentrations from 500 Monte-Carlo simulation cases. Each open circle represents concentrations from one of the 500 runs. The two gray dashed lines are the thresholds separating flushing (red, $b>0.1$ ) and dilution (blue, $b<0.1$ ) patterns from chemostatic (gray, $-0.1<=b<=0.1$ ) patterns. This figure shows that as long as $\mathrm{C}_{\mathrm{sw}} / \mathrm{C}_{\mathrm{dw}}>$ 1.7, nitrate exhibits flushing patterns (red); when $\mathrm{C}_{\mathrm{sw}} / \mathrm{C}_{\mathrm{dw}}<0.8$, nitrate export exhibits dilution patterns (blue).

\section{Supplementary Tables}

Table S1. Hydrology calibration: key land-surface and soil parameters

\begin{tabular}{lll}
\hline Parameter & Calibrated value & Parameter note \\
\hline$C_{\text {zil }}$ & 7.13 & Zilitinkevich coefficient \\
$D_{\text {root }}$ & 0.34 & Rooting depth $(\mathrm{m})$ \\
RGL & 0.80 & Reference visible solar radiation $\left(\mathrm{W} / \mathrm{m}^{2}\right)$ \\
$\mathrm{RS}$ & 0.89 & Minimum stomatal resistance $(\mathrm{s} / \mathrm{m})$
\end{tabular}




\begin{tabular}{lll}
\hline Parameter & Calibrated value & Parameter note \\
\hline HS & 1.42 & Water vapor exchange coefficient \\
$\mathbf{K}_{\text {satH }}$ & 1.32 & Horizontal saturated hydraulic conductivity $(\mathrm{m} / \mathrm{d})$ \\
$\mathbf{K}_{\text {satV }}$ & 26.7 & Vertical saturated hydraulic conductivity $(\mathrm{m} / \mathrm{d})$ \\
$K_{\text {inf }}$ & 0.76 & Infiltration hydraulic conductivity $(\mathrm{m} / \mathrm{d})$ \\
$D_{\text {mac }}$ & 0.31 & Macropore depth $(\mathrm{m})$ \\
$\theta$ & 0.41 & Porosity $\left(\mathrm{m}^{3} / \mathrm{m}^{3}\right)$ \\
$\alpha$ & 4.67 & van Genuchten alpha, inversely proportional to pore diameter $\left(\mathrm{m}^{-1}\right)$ \\
$\mathbf{n}$ & 1.88 & van Genuchten $\mathrm{n}$, inversely proportional to water retention \\
$Z_{\text {soil }}$ & 1.0 & soil thickness $(\mathrm{m})$ \\
\hline
\end{tabular}

Note that soil properties are initially estimated using pedotransfer function (Wösten et al., 2001) based on soil composition derived from the SSURGO database. Bolded parameters are the most sensitive parameters that reproduced stream discharge.

\section{Reference:}

Armfield, J., Perdrial, J., Gagnon, A., Ehrenkranz, J., Perdrial, N., Cincotta, M., Ross, D., Shanley, J., Underwood, K., Ryan, P. 2018. Does stream water composition at Sleepers River in Vermont reflect dynamic changes in soils during recovery from acidification? Frontiers in Earth Science, , 6 , 246.

Association, M.G. 2018. Drain tiles and groundwater resources: Understanding the relations. Minnesota Ground Water Association.

Baker, L.A., Hope, D., Xu, Y., Edmonds, J., Lauver, L. 2001. Nitrogen balance for the Central ArizonaPhoenix (CAP) ecosystem.Ecosystems , 4 (6), 582-602.

Bao, C., Li, L., Shi, Y., Duffy, C. 2017. Understanding watershed hydrogeochemistry: 1. Development of RT-Flux-PIHM. Water Resour. Res., 53 (3), 2328-2345.

Barnes, R.T., Raymond, P.A. 2010. Land-use controls on sources and processing of nitrate in small watersheds: insights from dual isotopic analysis. Ecological Applications , 20 (7), 1961-1978.

Basu, N.B., Destouni, G., Jawitz, J.W., Thompson, S.E., Loukinova, N.V., Darracq, A., Zanardo, S., Yaeger, M., Sivapalan, M., Rinaldo, A. 2010. Nutrient loads exported from managed catchments reveal emergent biogeochemical stationarity. Geophysical Research Letters ,37 (23).

Basu, N.B., Thompson, S.E., Rao, P.S.C. 2011. Hydrologic and biogeochemical functioning of intensively managed catchments: A synthesis of top-down analyses. Water Resources Research ,47 (10).

Bishop, K., Seibert, J., Kohler, S., Laudon, H. 2004. Resolving the Double Paradox of rapidly mobilized old water with highly variable responses in runoff chemistry. Hydrological Processes ,18 (1), 185-189.

Blann, K.L., Anderson, J.L., Sands, G.R., Vondracek, B. 2009. Effects of Agricultural Drainage on Aquatic Ecosystems: A Review. Critical Reviews in Environmental Science and Technology, 39 (11), 909-1001.

Boyer, E.W., Goodale, C.L., Jaworski, N.A., Howarth, R.W. 2002. Anthropogenic nitrogen sources and relationships to riverine nitrogen export in the northeastern USA. Biogeochemistry, 57 (1), 137-169.

Brantley, S.L., Lebedeva, M.I., Balashov, V.N., Singha, K., Sullivan, P.L., Stinchcomb, G. 2017. Toward a conceptual model relating chemical reaction fronts to water flow paths in hills. Geomorphology ,277 , $100-117$.

Brantley, S.L., White, T., West, N., Williams, J.Z., Forsythe, B., Shapich, D., Kaye, J., Lin, H., Shi, Y., Kaye, M. 2018. Susquehanna Shale Hills Critical Zone Observatory: Shale Hills in the context of Shaver's Creek watershed. Vadose Zone Journal, 17 (1). 
Burow, K.R., Nolan, B.T., Rupert, M.G., Dubrovsky, N.M. 2010. Nitrate in groundwater of the United States, 1991- 2003. Environmental Science \&3 Technology , 44 (13), 4988-4997.

Cowie, R.M., Knowles, J.F., Dailey, K.R., Williams, M.W., Mills, T.J., Molotch, N.P. 2017. Sources of streamflow along a headwater catchment elevational gradient. Journal of Hydrology , 549 , 163-178.

Creed, I., Band, L. 1998. Export of nitrogen from catchments within a temperate forest: evidence for a unifying mechanism regulated by variable source area dynamics. Water Resources Research ,34 (11), 3105-3120.

Creed, I., Band, L., Foster, N., Morrison, I., Nicolson, J., Semkin, R., Jeffries, D. 1996. Regulation of nitrate-N release from temperate forests: A test of the $\mathrm{N}$ flushing hypothesis. Water Resources Research, 32 (11), 3337-3354.

Diamond, J.S., Cohen, M.J. 2018. Complex patterns of catchment solute-discharge relationships for coastal plain rivers.Hydrological Processes, 32 (3), 388-401.

Diaz, R.J., Rosenberg, R. 2008. Spreading dead zones and consequences for marine ecosystems. science, 321 (5891), 926-929.

Dittman, J.A., Driscoll, C.T., Groffman, P.M., Fahey, T.J. 2007. Dynamics of nitrogen and dissolved organic carbon at the Hubbard Brook Experimental Forest. Ecology , 88 (5), 1153-1166.

Divers, M.T., Elliott, E.M., Bain, D.J. 2013. Constraining Nitrogen Inputs to Urban Streams from Leaking Sewers Using Inverse Modeling: Implications for Dissolved Inorganic Nitrogen (DIN) Retention in Urban Environments. Environmental Science \& Technology ,47 (4), 1816-1823.

Divers, M.T., Elliott, E.M., Bain, D.J. 2014. Quantification of nitrate sources to an urban stream using dual nitrate isotopes. Environmental science $\&$ technology , 48 (18), 10580-10587.

Dodds, W.K., Lopez, A.J., Bowden, W.B., Gregory, S., Grimm, N.B., Hamilton, S.K., Hershey, A.E., Marti, E., McDowell, W.H., Meyer, J.L., Morrall, D., Mulholland, P.J., Peterson, B.J., Tank, J.L., Valett, H.M., Webster, J.R., Wollheim, W. 2002. N uptake as a function of concentration in streams. Journal of the North American Benthological Society, 21 (2), 206-220.

Duncan, J.M., Welty, C., Kemper, J.T., Groffman, P.M., Band, L.E. 2017. Dynamics of nitrate concentration-discharge patterns in an urban watershed. Water Resources Research , 53 (8), 7349-7365.

Eghbali Babadi, F., Yunus, R., Abbasi, A., Masoudi Soltani, S. 2019. Response Surface Method in the Optimization of a Rotary Pan-Equipped process for Increased Efficiency of Slow-Release Coated Urea.Processes , 7 (3), 125.

Galloway, J.N., Dentener, F.J., Capone, D.G., Boyer, E.W., Howarth, R.W., Seitzinger, S.P., Asner, G.P., Cleveland, C.C., Green, P., Holland, E.A. 2004. Nitrogen cycles: past, present, and future.Biogeochemistry , 70 (2), 153-226.

Godsey, S.E., Kirchner, J.W., Clow, D.W. 2009. Concentration-discharge relationships reflect chemostatic characteristics of US catchments. Hydrological Processes , 23 (13), 1844-1864.

Gran, K.B., Dolph, C., Baker, A., Bevis, M., Cho, S.J., Czuba, J.A., Dalzell, B., Danesh-Yazdi, M., Hansen, A.T., Kelly, S., Lang, Z., Schwenk, J., Belmont, P., Finlay, J.C., Kumar, P., Rabotyagov, S., Roehrig, G., Wilcock, P., Foufoula-Georgiou, E. 2019. The Power of Environmental Observatories for Advancing Multidisciplinary Research, Outreach, and Decision support: The Case of the Minnesota River Basin. Water Resources Research , 55 (4), 3576-3592.

Grimm, N.B., Faeth, S.H., Golubiewski, N.E., Redman, C.L., Wu, J., Bai, X., Briggs, J.M. 2008. Global change and the ecology of cities.science, $\mathbf{3 1 9}$ (5864), 756-760. 
Groffman, P.M., Bain, D.J., Band, L.E., Belt, K.T., Brush, G.S., Grove, J.M., Pouyat, R.V., Yesilonis, I.C., Zipperer, W.C. 2003. Down by the riverside: urban riparian ecology. Frontiers in Ecology and the Environment, 1 (6), 315-321.

Hagedorn, F., Bucher, J.B., Schleppi, P. 2001. Contrasting dynamics of dissolved inorganic and organic nitrogen in soil and surface waters of forested catchments with Gleysols. Geoderma, 100 (1), 173-192.

Hamamoto, S., Moldrup, P., Kawamoto, K., Komatsu, T. 2010. Excluded-volume expansion of Archie's law for gas and solute diffusivities and electrical and thermal conductivities in variably saturated porous media. Water Resources Research , 46 (6).

Hararuk, O., Smith, M.J., Luo, Y. 2015. Microbial models with data-driven parameters predict stronger soil carbon responses to climate change. Glob. Chang. Biol. , 21 (6), 2439-53.

Herndon, E.M., Dere, A.L., Sullivan, P.L., Norris, D., Reynolds, B., Brantley, S.L. 2015. Landscape heterogeneity drives contrasting concentration-discharge relationships in shale headwater catchments. Hydrology and earth system sciences, 19 (8), 3333-3347.

Hill, A.R. 1996. Nitrate Removal in Stream Riparian Zones. Journal of Environmental Quality , 25 , 743-755.

Hoagland, B., Russo, T.A., Gu, X., Hill, L., Kaye, J., Forsythe, B., Brantley, S.L. 2017. Hyporheic zone influences on concentration-discharge relationships in a headwater sandstone stream. Water Resources Research , 53 (6), 4643-4667.

Hooper, R.P., Christophersen, N., Peters, N.E. 1990. Modelling streamwater chemistry as a mixture of soilwater end-members - An application to the Panola Mountain catchment, Georgia, U.S.A.Journal of Hydrology , 116 (1-4), 321-343.

Howarth, R.W., Sharpley, A., Walker, D. 2002. Sources of nutrient pollution to coastal waters in the United States: Implications for achieving coastal water quality goals. Estuaries , 25 (4), 656-676.

Huang, J.-C., Lee, T.-Y., Kao, S.-J., Hsu, S.-C., Lin, H.-J., Peng, T.-R. 2012. Land use effect and hydrological control on nitrate yield in subtropical mountainous watersheds. Hydrology and Earth System Sciences , 16 (3), 699-714.

Hyer, K.E., Denver, J.M., Langland, M.J., Webber, J.S., Bohlke, J., Hively, W.D., Clune, J.W. 2016. Spatial and temporal variation of stream chemistry associated with contrasting geology and land-use patterns in the Chesapeake Bay watershed - Summary of results from Smith Creek, Virginia; Upper Chester River, Maryland; Conewago Creek, Pennsylvania; and Difficult Run, Virginia, 2010-2013. US Geological Survey. 2328-0328.

Jacobs, S.R., Weeser, B., Guzha, A.C., Rufino, M.C., Butterbach-Bahl, K., Windhorst, D., Breuer, L. 2018. Using High-Resolution Data to Assess Land Use Impact on Nitrate Dynamics in East African Tropical Montane Catchments. Water Resources Research , 54 (3), 1812-1830.

Jawitz, J.W., Mitchell, J. 2011. Temporal inequality in catchment discharge and solute export. Water Resources Research, 47 (10).

Jiang, R., Woli, K.P., Kuramochi, K., Hayakawa, A., Shimizu, M., Hatano, R. 2010. Hydrological process controls on nitrogen export during storm events in an agricultural watershed. Soil Science $\mathcal{E}$ Plant Nutrition , 56 (1), $72-85$.

Jurgensen, M.F., Page-Dumroese, D.S., Brown, R.E., Tirocke, J.M., Miller, C.A., Pickens, J.B., Wang, M. 2017. Estimating carbon and nitrogen pools in a forest soil: influence of soil bulk density methods and rock content. Soil Science Society of America Journal ,81 (6), 1689-1696.

Kaushal, S.S., Belt, K.T. 2012. The urban watershed continuum: evolving spatial and temporal dimensions. Urban Ecosystems ,15 (2), 409-435. 
Kaushal, S.S., Delaney-Newcomb, K., Findlay, S.E.G., Newcomer, T.A., Duan, S.W., Pennino, M.J., Sivirichi, G.M., Sides-Raley, A.M., Walbridge, M.R., Belt, K.T. 2014. Longitudinal patterns in carbon and nitrogen fluxes and stream metabolism along an urban watershed continuum. Biogeochemistry, 121 (1), 23-44.

Kaushal, S.S., Groffman, P.M., Band, L.E., Shields, C.A., Morgan, R.P., Palmer, M.A., Belt, K.T., Swan, C.M., Findlay, S.E., Fisher, G.T. 2008. Interaction between urbanization and climate variability amplifies watershed nitrate export in Maryland. Environmental Science \&3 Technology , 42 (16), 5872-5878.

Kaushal, S.S., Likens, G.E., Utz, R.M., Pace, M.L., Grese, M., Yepsen, M. 2013. Increased river alkalinization in the Eastern US.Environmental science \& technology , 47 (18), 10302-10311.

King, K.W., Williams, M.R., Macrae, M.L., Fausey, N.R., Frankenberger, J., Smith, D.R., Kleinman, P.J.A., Brown, L.C. 2015. Phosphorus Transport in Agricultural Subsurface Drainage: A Review. Journal of Environmental Quality, 44 (2), 467-485.

Kolbe, T., De Dreuzy, J.-R., Abbott, B.W., Aquilina, L., Babey, T., Green, C.T., Fleckenstein, J.H., Labasque, T., Laverman, A.M., Marcais, J. 2019. Stratification of reactivity determines nitrate removal in groundwater. Proceedings of the National Academy of Sciences ,116 (7), 2494-2499.

LaBaugh, J.W., Harte, P.T., Shapiro, A.M., Hsieh, P.A., Johnson, C.D., Goode, D.J., Wood, W.W., Buso, D.C., Likens, G.E., Winter, T.C. 2013. Physical, chemical, and isotopic data from groundwater in the watershed of Mirror Lake, and in the vicinity of Hubbard Brook, near West Thornton, New Hampshire, 1983 to 1997. US Geological Survey. 2331-1258.

Le Moal, M., Gascuel-Odoux, C., Menesguen, A., Souchon, Y., Etrillard, C., Levain, A., Moatar, F., Pannard, A., Souchu, P., Lefebvre, A. 2019. Eutrophication: a new wine in an old bottle? Science of the Total Environment, 651, 1-11.

Lerner, D.N., Yang, Y.S., Barrett, M.H., Tellam, J.H. 1999. Loadings of non-agricultural nitrogen in urban groundwater. Impacts of Urban Growth on Surface Water and Groundwater Quality (259), 117-123.

Li, L. 2019. Watershed Reactive Transport. in: Reactive transport modeling in natural and engineered system , Vol. 85, Society of Mineralogy and Geochemistry. Reviews in Mineralogy \& Geochemistry.

Li, L., Bao, C., Sullivan, P.L., Brantley, S., Shi, Y., Duffy, C. 2017. Understanding watershed hydrogeochemistry: 2. Synchronized hydrological and geochemical processes drive stream chemostatic behavior. Water Resources Research , 53 (3), 2346-2367.

Luthy, R.G., Sedlak, D.L., Plumlee, M.H., Austin, D., Resh, V.H. 2015. Wastewater-effluent-dominated streams as ecosystem-management tools in a drier climate. Frontiers in Ecology and the Environment ,13 (9), 477-485.

Machesky, M.L., Holm, T.R., Slowikowski, J.A. 2010. Phosphorus speciation in stream bed sediments from an agricultural watershed: Solid-phase associations and sorption behavior. Aquatic geochemistry , 16 (4), 639-662.

Marti, E., Riera, J.L., Sabater, F. 2010. Effects of Wastewater Treatment Plants on Stream Nutrient Dynamics Under Water Scarcity Conditions. Water Scarcity in the Mediterranean: Perspectives under Global Change , 8 , 173-195.

Mayer, B., Boyer, E.W., Goodale, C., Jaworski, N.A., Van Breemen, N., Howarth, R.W., Seitzinger, S., Billen, G., Lajtha, K., Nadelhoffer, K. 2002. Sources of nitrate in rivers draining sixteen watersheds in the northeastern US: Isotopic constraints. Biogeochemistry ,57 (1), 171-197.

Miller, M.P., Tesoriero, A.J., Hood, K., Terziotti, S., Wolock, D.M. 2017. Estimating Discharge and Nonpoint Source Nitrate Loading to Streams From Three End-Member Pathways Using High-Frequency Water Quality Data. Water Resources Research, 53 (12), 10201-10216. 
Moatar, F., Abbott, B.W., Minaudo, C., Curie, F., Pinay, G. 2017. Elemental properties, hydrology, and biology interact to shape concentration-discharge curves for carbon, nutrients, sediment, and major ions. Water Resources Research, 53 (2), 1270-1287.

Montross, G.G., McGlynn, B.L., Montross, S.N., Gardner, K.K. 2013. Nitrogen production from geochemical weathering of rocks in southwest Montana, USA. Journal of Geophysical Research: Biogeosciences ,118 (3), 1068-1078.

Mulholland, P.J., Helton, A.M., Poole, G.C., Hall, R.O., Hamilton, S.K., Peterson, B.J., Tank, J.L., Ashkenas, L.R., Cooper, L.W., Dahm, C.N., Dodds, W.K., Findlay, S.E.G., Gregory, S.V., Grimm, N.B., Johnson, S.L., McDowell, W.H., Meyer, J.L., Valett, H.M., Webster, J.R., Arango, C.P., Beaulieu, J.J., Bernot, M.J., Burgin, A.J., Crenshaw, C.L., Johnson, L.T., Niederlehner, B.R., O’Brien, J.M., Potter, J.D., Sheibley, R.W., Sobota, D.J., Thomas, S.M. 2008. Stream denitrification across biomes and its response to anthropogenic nitrate loading. Nature ,452 (7184), 202-U46.

Musolff, A., Fleckenstein, J.H., Rao, P.S.C., Jawitz, J.W. 2017. Emergent archetype patterns of coupled hydrologic and biogeochemical responses in catchments. Geophysical Research Letters ,44 (9), 4143-4151.

Musolff, A., Schmidt, C., Selle, B., Fleckenstein, J.H. 2015. Catchment controls on solute export. Advances in Water Resources ,86 , 133-146.

Newcomer Johnson, T.A., Kaushal, S.S., Mayer, P.M., Grese, M.M. 2014. Effects of stormwater management and stream restoration on watershed nitrogen retention. Biogeochemistry, 121 (1), 81-106.

Pellerin, B.A., Saraceno, J.F., Shanley, J.B., Sebestyen, S.D., Aiken, G.R., Wollheim, W.M., Bergamaschi, B.A. 2012. Taking the pulse of snowmelt: in situ sensors reveal seasonal, event and diurnal patterns of nitrate and dissolved organic matter variability in an upland forest stream. Biogeochemistry, 108 (1-3), 183-198.

Pellerin, B.A., Wollheim, W.M., Feng, X., Vorosmarty, C.J. 2008. The application of electrical conductivity as a tracer for hydrograph separation in urban catchments. Hydrological Processes: An International Journal , 22 (12), 1810-1818.

Pennino, M.J., Kaushal, S.S., Mayer, P.M., Utz, R.M., Cooper, C.A. 2016. Stream restoration and sewers impact sources and fluxes of water, carbon, and nutrients in urban watersheds. Hydrology and Earth System Sciences , 20 (8), 3419-3439.

Perrin, A.-S., Probst, A., Probst, J.-L. 2008. Impact of nitrogenous fertilizers on carbonate dissolution in small agricultural catchments: Implications for weathering $\mathrm{CO} 2$ uptake at regional and global scales. Geochimica et Cosmochimica Acta , 72 (13), 3105-3123.

Pickett, S.T., Cadenasso, M.L., Grove, J.M., Boone, C.G., Groffman, P.M., Irwin, E., Kaushal, S.S., Marshall, V., McGrath, B.P., Nilon, C.H. 2011. Urban ecological systems: Scientific foundations and a decade of progress. Journal of Environmental Management, 92 (3), 331-362.

Poor, C.J., McDonnell, J.J. 2007. The effects of land use on stream nitrate dynamics. Journal of Hydrology , 332 (1-2), 54-68.

Prein, A.F., Rasmussen, R.M., Ikeda, K., Liu, C., Clark, M.P., Holland, G.J. 2017. The future intensification of hourly precipitation extremes. Nature Climate Change, 7 (1), 48-52.

Raffensperger, J.P., Baker, A.C., Blomquist, J.D., Hopple, J.A. 2017.Optimal hydrograph separation using a recursive digital filter constrained by chemical mass balance, with application to selected Chesapeake Bay watersheds. US Geological Survey.

Royer, T.V., David, M.B., Gentry, L.E. 2006. Timing of riverine export of nitrate and phosphorus from agricultural watersheds in Illinois: Implications for reducing nutrient loading to the Mississippi River.Environmental Science \& Technology , 40 (13), 4126-4131. 
Sebestyen, S.D., Boyer, E.W., Shanley, J.B., Kendall, C., Doctor, D.H., Aiken, G.R., Ohte, N. 2008. Sources, transformations, and hydrological processes that control stream nitrate and dissolved organic matter concentrations during snowmelt in an upland forest. Water Resources Research, 44 (12).

Sebilo, M., Mayer, B., Nicolardot, B., Pinay, G., Mariotti, A. 2013. Long-term fate of nitrate fertilizer in agricultural soils.Proceedings of the National Academy of Sciences of the United States of America, 110 (45), 18185-18189.

Seibert, J., Grabs, T., Kohler, S., Laudon, H., Winterdahl, M., Bishop, K. 2009. Linking soil- and streamwater chemistry based on a Riparian Flow-Concentration Integration Model. Hydrol. Earth Syst. Sci. ,13 (12), 2287-2297.

Shepherd, M., Ghani, A., Rajendram, G., Carlson, B., Pirie, M. 2015. Soil total nitrogen concentration explains variation in pasture response to spring nitrogen fertiliser across a single farm. Nutrient Cycling in Agroecosystems , 101 (3), 377-390.

Shi, Y., Davis, K.J., Zhang, F., Duffy, C.J. 2014. Evaluation of the parameter sensitivities of a coupled land surface hydrologic model at a critical zone observatory. Journal of Hydrometeorology ,15 (1), 279-299.

Sickman, J.O., Leydecker, A., Chang, C.C., Kendall, C., Melack, J.M., Lucero, D.M., Schimel, J. 2003. Mechanisms underlying export of $\mathrm{N}$ from high-elevation catchments during seasonal transitions.Biogeochemistry , 64 (1), 1-24.

Spahr, N.E., Dubrovsky, N.M., Gronberg, J.M., Franke, O., Wolock, D.M. 2010. Nitrate loads and concentrations in surface-water base flow and shallow groundwater for selected basins in the United States, water years 1990-2006. U. S. Geological Survey.

Sudduth, E.B., Perakis, S.S., Bernhardt, E.S. 2013. Nitrate in watersheds: Straight from soils to streams? Journal of Geophysical Research-Biogeosciences , 118 (1), 291-302.

Tedesco, L., Pascual, D., Shrake, L., Casey, L., Hall, B., Vidon, P., Hernly, F., Barr, R., Ulmer, J., Pershing, D. 2005. Eagle Creek watershed management plan: An integrated approach to improved water quality. Eagle creek watershed alliance, CEES publication ,7 , 182.

Tesoriero, A.J., Terziotti, S., Abrams, D.B. 2015. Predicting Redox Conditions in Groundwater at a Regional Scale. Environmental Science \& Technology , 49 (16), 9657-9664.

Thompson, S., Basu, N., Lascurain, J., Aubeneau, A., Rao, P. 2011. Relative dominance of hydrologic versus biogeochemical factors on solute export across impact gradients. Water Resources Research, $\mathbf{4 7}$ (10).

Van Cappellen, P., Maavara, T. 2016. Rivers in the Anthropocene: Global scale modifications of riverine nutrient fluxes by damming. Ecohydrology $\& 3$ Hydrobiology , 16 (2), 106-111.

Van Meter, K., Basu, N., Van Cappellen, P. 2017. Two centuries of nitrogen dynamics: Legacy sources and sinks in the Mississippi and Susquehanna River Basins. Global Biogeochemical Cycles ,31 (1), 2-23.

Van Meter, K.J., Basu, N.B. 2015. Catchment legacies and time lags: A parsimonious watershed model to predict the effects of legacy storage on nitrogen export. PLoS One, 10 (5), e0125971.

Van Meter, K.J., Basu, N.B., Veenstra, J.J., Burras, C.L. 2016. The nitrogen legacy: emerging evidence of nitrogen accumulation in anthropogenic landscapes. Environmental Research Letters ,11 (3), 035014.

Vidon, P.G.F., Hill, A.R. 2004. Landscape controls on nitrate removal in stream riparian zones. Water Resources Research , 40 (3).

Weiler, M., McDonnell, J.R.J. 2006. Testing nutrient flushing hypotheses at the hillslope scale: A virtual experiment approach. J. Hydrol. , 319 (1-4), 339-356.

Weitzman, J.N., Kaye, J.P. 2018. Nitrogen Budget and Topographic Controls on Nitrous Oxide in a ShaleBased Watershed. Journal of Geophysical Research: Biogeosciences, 123 (6), 1888-1908. 
Wollheim, W.M., Pellerin, B.A., Vorosmarty, C.J., Hopkinson, C.S. 2005. N retention in urbanizing headwater catchments. Ecosystems ,8 (8), 871-884.

Woo, D.K., Kumar, P. 2019. Impacts of Subsurface Tile Drainage on Age - Concentration Dynamics of Inorganic Nitrogen in Soil. Water Resources Research , 55 (2), 1470-1489.

Wosten, J., Pachepsky, Y.A., Rawls, W. 2001. Pedotransfer functions: bridging the gap between available basic soil data and missing soil hydraulic characteristics. Journal of hydrology, 251 (3-4), 123-150.

Yan, Z.F., Liu, C.X., Todd-Brown, K.E., Liu, Y.Y., Bond-Lamberty, B., Bailey, V.L. 2016. Porescale investigation on the response of heterotrophic respiration to moisture conditions in heterogeneous soils.Biogeochemistry, 131 (1-2), 121-134.

Zamanian, K., Zarebanadkouki, M., Kuzyakov, Y. 2018. Nitrogen fertilization raises CO2 efflux from inorganic carbon: A global assessment. Global Change Biology , 24 (7), 2810-2817.

Zhang, Q. 2018. Synthesis of nutrient and sediment export patterns in the Chesapeake Bay watershed: Complex and non-stationary concentration-discharge relationships. Science of the Total Environment, 618 , 1268-1283.

Zhi, W., Li, L., Dong, W.M., Brown, W., Kaye, J., Steefel, C., Williams, K.H. 2019. Distinct Source Water Chemistry Shapes Contrasting Concentration-Discharge Patterns. Water Resources Research ,55 (5), 4233-4251.

Zhou, T., Shi, P., Hui, D., Luo, Y. 2009. Global pattern of temperature sensitivity of soil heterotrophic respiration (Q10) and its implications for carbon-climate feedback. Journal of Geophysical Research: Biogeosciences, 114 (G2). 